\title{
El ornato esculpido en el templo de Fernando I (San Juan Bautista/San Isidoro de León)
}

\author{
The sculpted ornament in the church of Fernando I \\ (San Juan Bautista/San Isidoro de León)
}

José Alberto MORÁIS MORÁN*

Pontificia Universidad Católica de Valparaíso-Chile. Instituto de Historia

Recibido: 5-V-2014 / Aceptado: 4-VII-2014

RESUMEN: El autor investiga nuevos vestigios escultóricos datados a mediados del siglo XI y procedentes de la desaparecida iglesia del rey Fernando I en León, dedicada primero a San Juan Bautista y, a partir del año 1063, a San Isidoro.

A partir del análisis de algunas piezas del tesoro de aquel templo, y la aportación de nueva documentación sobre un cancel y una arqueta de piedra, se reflexiona sobre la precoz adopción de los lenguajes románicos en aquel contexto, muy desconocido ante la pérdida casi total de sus ornamentos.

Palabras clave: Iglesia de Fernando I, Escultura en piedra, Arqueta, Cancel, San Juan Bautista, San Isidoro de León.

ABSTRACT: The author investigates new sculptural traces that date from the mid-eleventh century and coming from the missing King Fernando I's church, first dedicated to San Juan Bautista, and after 1063, to San Isidoro.

From the analysis of some parts of the treasure of that temple, and the contribution of new documents about a chancel screen and a stone casket, it was reflected on the early adoption of Romanesque languages in that context, highly unknown with the almost total loss of their ornaments.

Keywords: Fernando I's church, Stone sculpture, Casket, Chancel screen, San Juan Bautista, San Isidoro de León.

¿Sabes quién decidió cuánto habría de medir y quién fue el arquitecto que la hizo? ¿Sobre qué descansan sus cimientos? ¿Quién le puso la piedra principal de apoyo? ¡Dímelo tú, si de veras sabes tanto!

(Job, 38: 4-6)
No resulta fácil encontrar un fenómeno historiográfico tan complejo e interesante como el surgido en torno a la figura del rey Fernando I (1016-1065) y la comitencia de ciertas obras arquitectónicas y plásticas en el monasterio de San Juan Bautista, más tarde San Isidoro, en el León del siglo XI. 
Pocos edificios han provocado tantas controversias heredadas, sin duda, de las corrientes metodológicas atribucionistas. El investigador que valora las informaciones vertidas en los trabajos científicos publicados hasta el día de hoy, acaba por mostrarse dubitativo ante la diversidad de opiniones, las teorías enfrentadas y, por encima de todo, ante la imposible tarea de reconstruir un patrimonio prácticamente perdido.

Uno de los puntos más conflictivos, precisamente por su total destrucción, recae en la primitiva construcción que el citado rey y su esposa la reina Sancha erigieron en honor de San Juan Bautista y San Pelayo, asentada, según indican las fuentes y la misma arqueología, sobre un templo anterior constituido bajo la comitencia del monarca Alfonso V. Se trata de un tema candente, resucitado especialmente tras las recientes aportaciones del Dr. Gerardo Boto en torno a las cuestiones edilicias ${ }^{1}$.

Como es sabido, el templo construido por el monarca fue el escenario primordial que acogió los momentos más importantes de su reinado. Por todos es conocido que allí fueron depositadas las reliquias del santo

*Agradezco las opiniones dadas durante la realización de este estudio por: Etelvina Fernández González (Universidad de León), Gerardo Boto Varela (Universitat de Girona), Achim Arbeiter (Georg-August-Universität Göttingen), María Cruz Villalón (Universidad de Extremadura), Elizabeth Valdez del Alamo (Montclair State University), Sabine Noack-Halley, Encarnación Martín López (Universidad de León), Elisabeth Fragoso Pulido (Museo Nacional de Arte Romano), Javier Martínez Ruiz (Director del Museo y Claustro románico del Monasterio de Silos), Juan Antonio Olañeta (Amigos del Románico), Victoriano Nodar Fernández (Universidade de Santiago de Compostela) y la experta informática y siempre paciente Mercedes Rodríguez Andrés.

${ }^{1} \mathrm{G}$. BOTO VARELA, "Morfogénesis espacial de las primeras arquitecturas de San Isidoro. Vestigios de la memoria dinástica leonesa", Siete maravillas del Románico Español, Aguilar de Campoo, 2009, pp. 151-191 e ÍDEM, "In Legionenssy regum ciminterio. La construcción del cuerpo occidental de San Isidoro de León y el amparo de los invitados a la Cena del Señor", Monumentos Singulares del Románico. Nuevas lecturas sobre formas y usos, Aguilar de Campoo, 2012, pp. 91-135. hispalense a su llegada a León el 21 de diciembre de $1063^{2}$. Bajo las bóvedas de aquel templo el rey vivió sus últimas horas al compás de un ceremonial tan complejo como necesitado de un marco litúrgico digno en el que llevarlo a cabo ${ }^{3}$.

La historia es bien conocida. La súplica y petición a Dios impregnan los últimos momentos de la vida de Fernando I. La Primera Crónica General de España alude a la celebración de la liturgia de Navidad del año 1065, cuando el rey mandó llamar a obispos, abades y al resto de la corte. Se vistió con las ropas reales, puso sobre su cabeza la coro$\mathrm{na}^{4} \mathrm{y}$ ordenó que lo llevasen a aquella iglesia hoy perdida. Allí, ante la urna de San Isidoro, oró ${ }^{5}$. Lo sucedido a los pies de esta arca,

2 A. VIÑAYO GONZÁLEZ, "La llegada de San Isidoro a León. Datos para la historia del traslado del Cuerpo del Doctor de las Españas desde Sevilla a León (1063)", Archivos leoneses, 33, XVII, 1963, pp. 65-112 y E. FERNÁNDEZ GONZÁLEZ, "Imagen, devoción y suntuosidad en las aportaciones de Fernando I y Sancha al tesoro de San Isidoro de León", Monasterios y monarcas. Fundación, presencia y memoria regia en monasterios hispanos medievales, Aguilar de Campoo, 2012, pp. 160-197.

${ }^{3}$ C. J. BISHKO, "The Liturgical Context of Fernando I's Last Days According to the So-Called "Historia Silense", Spanish and Portuguese Monastic History 600-1300, Londres, 1984, VII, pp. 47-59 y M. VALDÉS FERNÁNDEZ, "El Panteón Real de la Colegiata de San Isidoro de León", Maravillas de la España medieval: Tesoro sagrado y monarquía, Valladolid, 2001, vol. I, pp. 73-84, en concreto, p. 75.

${ }^{4} \mathrm{~A}$ modo de hipótesis podría creerse que se trata de la corona citada en el privilegio de donación de Fernando I y Sancha del día 22 de diciembre de 1063. En él se alude a tres coronas y al menos una debió servir de uso personal al monarca: "Tertia uero est diadema capitis mihi aureum et arcellina de cristillo auro coperta". Es probable que se trate de la gemmatam coronam citada en la versión Silense de la Crónica de Sampiro, cuando narra el momento en el que los hombres de la corte llevaron al monarca ante la urna de San Isidoro: "et hec dicens, exuit regalem clamidem, que induabatur corpus, et deposuit gemmatam coronam, qua ambiebatur capuz, atque cum lacrimis, ecclesie solo postratus, pro delictorum venia Dominum attencius exorabat". Cf.: J. PÉREZ DE URBEL, Sampiro. Su crónica y la monarquía leonesa en el siglo X, Madrid, 1952, pp. 208-209.

${ }^{5}$ R. MÉNENDEZ PIDAL, Primera Crónica General de España, Madrid, 1977, tomo II, pp. 361-362. 
en aquel viejo edificio, marcaría para siempre la cultura visual del románico en San Isidoro $^{6}$. Su muerte fue una expiración ritual, postrado ante el altar de San Juan ${ }^{7}$, en el día del natalicio del santo. Este gesto tendría grandes consecuencias en las artes plásticas del futuro, desde la efigie del rey a los pies del Crucificado, pintada años más tarde en el panteón, al postramiento de Urraca a los pies de la cruz argéntea, hoy perdida y que Therese Martin ha comparado acertadamente con la comandada por la reina Gisela de Hungría ${ }^{8}$.

Las noticias que nos han llegado de aquella iglesia son tan escasas como contradictorias. Desde un punto de vista arquitectónico, como se ha dicho, existen trabajos específicos que abordaron la cuestión amplia

${ }^{6}$ G. CAVERO DOMÍNGUEZ, "El discurso de la Crónica silense: San Isidoro y el panteón real”, e-Spania, 14, 2012, consultado el 29 octubre 2013. URL: http://espania.revues.org/21612. Aunque a veces se criticó la sobrelectura de la muerte de Fernando I, sin embargo, uno de los Obituarios conservados en la Colegiata, concretamente el que se viene denominando Obituario 2, sólo incluye la mención de este monarca, anterior al establecimiento de los canónigos de San Isidoro: "et Fredenandus rex totius Yspanie qui transtulit corpus beati Isydori ab Yspali in Legione. Era $\mathrm{M}^{\mathrm{a}} \mathrm{C}^{\mathrm{a}} \mathrm{III} \mathrm{I}^{\mathrm{a}}$. El dato es relevante pues sabemos que con normalidad, la incorporación de la citación del fallecimiento al Obituario tenía lugar inmediatamente después de conocerse el hecho del óbito. A pesar de haber fallecido casi un siglo antes de la llegada de los canónigos regulares, el recuerdo del monarca seguía estando muy presente en la vida litúrgica de la comunidad. Ello justifica, así mismo, que sea uno de los pocos nombres añadidos al martirologio del Códice IV. Cf.: A. SUÁREZ GONZÁLEZ, “¿Del pergamino a la piedra? ¿de la piedra al pergamino? (entre diplomas, obituarios y epitafios medievales de San Isidoro de León)", Anuario de Estudios Medievales, 33/1, 2003, pp. 365-415, concretamente, p. 391, nota 91 .

${ }^{7}$ G. CAVERO DOMÍNGUEZ, Op. cit., p. 59 y J. BISHKO, Op. cit., p. 48.

${ }^{8}$ J. BISHKO, Op.cit., p. 51. Sobre la problemática cronológica del óbito del rey Fernando I, el autor se decanta por el 29 de diciembre. Véase también: T. MARTIN, "Mujeres, hermanas e hijas: el mecenazgo femenino en la familia de Alfonso VI", Anales de Historia del Arte, Volumen Extraordinario, 2, 2011, pp. 147-179. La obra de orfebrería se conserva en Bayerische Vewaltung der staatlichen Schlösser. y discutidamente, calificando al maltrecho edificio con adjetivos nada generosos ${ }^{9}$.

Desde Ambrosio de Morales la tendencia de adjudicar la construcción del panteón y su iglesia anexa al rey Fernando I se asentó sin titubeos entre los discursos de los más acreditados eruditos ${ }^{10}$. Para Quadrado el templo románico actual y el panteón fueron igualmente obra del monarca ${ }^{11}$. Risco consideró, de la misma forma, que los dos ábsides románicos que hoy vemos, así como el central desaparecido, correspondían igualmente a época fernandina ${ }^{12}$, opinión que sigue Policarpo Mingote en $1879^{13}$.

A los autores modernos nada ayudó la inscripción que originariamente debió ubicarse en el tímpano del vano a poniente del templo fernandino, tal y como han argumentado Gerardo Boto y Frank Seehausen ${ }^{14}$ y que más tarde sería removida, cuando la vio Sandoval, quién escribe sobre ella: "la una que está en un pilar de dos arquitos que sirven de luces, que entran del claustro a la capilla, la cual piedra es de las mejores y más bien escritas que he visto; y que en ella no puede haber duda" (la transcribe) ${ }^{15}$.

${ }^{9}$ Una puesta al día de la bibliografía sobre el tema en: G. BOTO VARELA, “Morfogénesis...", pp. 151191. No obstante remito al fundamental trabajo de: $H$. SCHLUNK y J. MANZANARES, "La iglesia de San Pedro de Teverga y los comienzos del arte románico en el reino de Asturias y León", Archivo Español de Arte, 24, 1951, pp. 277-305.

${ }^{10} \mathrm{~A}$. DE MORALES, Viaje a los reynos de León y Galicia, y principado de Asturias, Madrid, 1572, (ed. 1765), pp. 41-46.

${ }^{11} \mathrm{~J}$. M. QUADRADO, Recuerdos y Bellezas de España. Asturias y León, Madrid, 1855, pp. 340-343.

${ }^{12} \mathrm{M}$. RISCO, Iglesia de León y monasterios antiguos y modernos de la misma ciudad, Madrid, 1792, p. 145.

${ }^{13}$ P. MINGOTE, Guía del viajero en León y su provincia, León, 1879, p. 171.

${ }^{14}$ F. SEEHAUSEN, “Wege zum Heil - Betrachterlenkung durch Architektur, Skulptur und Ausmalung im Panteón de los Reyes in León", kunsttexte.de, 4, 2009, pp. 1-37, particularmente, p. 22.

${ }^{15} \mathrm{P}$. DE SANDOVAL, Historia de los reyes de Castilla y León, Madrid, 1792, p. 50. Para Boto ocupó el timpa- 
Como se ha escrito hasta la saciedad, este relato decimonónico dio un vuelco con las primeras intervenciones arqueológicas en el suelo de la basílica. Entre los años 1908 y 1909 Juan Crisóstomo Torbado, a la sazón restaurador del templo románico, realizó las primeras excavaciones documentadas y de las que Díaz Jiménez daría cumplidas informaciones ${ }^{16}$. Sobre aquellos resultados basó el propio Mélida la publicación de una escueta nota donde ya remarcaba: "el panteón o narthex, y lo recién descubierto es la basílica que dedicada a San Juan Bautista existía en 966, reformada o reparada por Fernando I (1063)"17. El mismo Gómez-Moreno defendería la relación de esta estructura con las edificaciones asturianas, Valdediós y Lillo particularmente ${ }^{18}$.

Ha de señalarse convenientemente la relevancia del decenio 1951-1961 en el desarrollo de las investigaciones del, por entonces, desconocido edificio. En el primero de los años vio la luz el extenso artículo de Helmut Schlunk (1906-1982) y Joaquín Manzanares ${ }^{19} \mathrm{y}$, diez años más tarde, Luis Menéndez Pidal (1896-1975) consagraría la imagen de aquel templo para la posteridad, insistiendo en la simpleza de la construcción leonesa, emparentada ya para siempre

nillo de la puerta occidental de la iglesia fernandina. El Archivo del Instituto del Patrimonio Cultural de España conserva varias fotografías donde aún se observa el hueco que dejó la inscripción en época reciente, aunque más tarde fue reubicada en el lugar que ocupa hoy.

${ }^{16}$ J. E. DÍAZ JIMÉNEZ, “San Isidoro de León”, Boletín de la Sociedad española de Excursiones, 25, 1917, pp. 8198; I. GONZÁLEZ VARAS, La restauración monumental en España durante el siglo XIX, Valladolid, 2006 y J. PÉREZ GIL, "Los Torbado: el patrimonio leonés y la evolución de la Restauración arquitectónica en España", De Arte, 12, 2013, pp. 197-216.

${ }^{17}$ J. R. MÉLIDA, "La basílica legionense de San Isidoro", Boletín de la Real Academia de la Historia, 56, 1910, pp. 148-153.

${ }^{18}$ M. GÓMEZ-MORENO, Catálogo Monumental de la Provincia de León, Madrid, 1925, p. 180.

${ }^{19}$ H. SCHLUNK y J. MANZANARES, La iglesia de San Pedro de Teverga y los comienzos del arte románico en el reino de Asturias y León, Madrid, 1951, p. 302. con los modelos asturianos liderados por las iglesias de San Salvador de Valdediós y San Pedro de Teverga. Nunca más se dudaría ya de que aquellos eran fieles modelos/reflejos del templo desaparecido en León ${ }^{20}$.

En el año 1962, y a través del análisis plástico, Roberto Salvini (1912-1985) romperá con la teoría tradicional, desligando el panteón del patrocinio de Fernando I, para señalar a su hija Urraca como la comitente del espacio ${ }^{21}$. Ese año fue, sin duda, auténticamente referencial para la historiografía isidoriana, pues, paralelamente y con argumentos complementarios, Marcel Durliat (1917-2006) apoyaría la nueva datación ${ }^{22}$.

Finalmente, será John Williams quién, diez años más tarde, desarrollase otra campaña arqueológica cuyos resultados vieron la luz, parcialmente, entre los años 19691973. Pocos trabajos tuvieron tanto calado como el firmado por el profesor norteameri$\mathrm{cano}^{23}$. El impacto sobre la historiografía fue considerable y aún lo sigue siendo hoy en día. Del atribucionismo inicial que ensalzaba la figura de Fernando I como gran constructor, renovador de los lenguajes plásticos en los reinos medievales del norte hispano y constructor del panteón habría de pasarse a una postura contraria en beneficio de su hija la infanta Urraca (1033-1101). Todos conoce-

${ }^{20}$ L. MENÉNDEZ PIDAL, “Influencias y expansión de la arquitectura pre-románica asturiana, en alguna de sus manifestaciones", Archivos leoneses, 29-30, 1961, pp. 101-138. Para las relaciones entre la escultura de ambos espacios: A. VIÑAYO GONZÁLEZ, "Real Colegiata de San Isidoro de León", Enciclopedia del Románico en Castilla y León. León, Aguilar de Campoo, 2002, p. 547.

${ }^{21}$ R. SALVINI, La escultura románica en Europa, México, 1962, pp. 50-54 e ÍDEM, "Il problema cronologico del portico del San Isidoro di Leon e le origini della scultura romanica in Spagna", Medioevo nordico e medioevo mediterraneo, Florencia, 1987, pp. 437-448. En las últimas publicaciones, al contrario, dató entre 1054-1067 el templo fernandino y entre 1072-1101 el que llamaba pórtico de los reyes, bajo la comitencia de Urraca.

${ }^{22}$ M. DURLIAT, L'Art roman en l'Espagne, Paris, 1962 , p. 18.

${ }^{23}$ J. WILLIAMS, "San Isidoro in León: Evidence for a New History", Art Bulletin, 55, 1973, pp. 171-184. 
mos el tema y omito cualquier explicación al respecto ${ }^{24}$.

A pesar de los grandes cambios de atribución en lo referente estrictamente a la iglesia fernandina, para Williams, ayer como hoy, tanto la asturiana de San Salvador de Valdediós como la de Teverga, continuaron siendo los espejos en los que mirar para reconstruir el templo perdido en León ${ }^{25}$.

\footnotetext{
${ }^{24}$ Interesante compilación y comentario de la bibliografía norteamericana en: J. MANN, Romanesque Architecture and its Sculptural Decoration in Christian Spain, 1000-1120, Toronto, 2009. Para un resumen completo: A. GARCÍA MARTÍNEZ, "Aproximación crítica a la historiografía de San Isidoro de León", Estudios Humanísticos. Historia, 4, 2005, pp. 53-93 e ÍDEM, “El Panteón de San Isidoro de León. Estado de la cuestión y crítica historiográfica", Anuario del Departamento de Historia y Teoría del Arte, 16, 2004, pp. 9-16. Remito a las publicaciones donde se abordó el tema con amplia bibliografía: I. G. BANGO TORVISO, "El espacio para enterramientos privilegiados en la arquitectura medieval española", Anales del Departamento de Historia y Teoría del Arte, 4, 1992, pp. 93-132; E. VALDEZ DEL ALAMO, “Ortodoxia y heterodoxia en el estudio de la Escultura Románica Española: Estado de la cuestión", Anuario del Departamento de Historia y Teoría del Arte, 9-10, 1997-1998, pp. 9-33; E. FERNÁNDEZ GONZÁLEZ, San Isidoro de León, Madrid, 1992, p. 19; ÍDEM, “Reflexiones sobre la evolución hacia el Románico de las fórmulas artísticas altomedievales, en el ámbito astur-leonés, de la undécima centuria", Hispaniens Norden im 11. Jahrhundert. Christliche Kunst im Umbruch, Petersberg, 2010, pp. 4872, p. 50; M. VALDÉS FERNÁNDEZ, Op.cit., pp. 76-77; T. MARTIN, "The Art of a Reigning Queen as Dynastic Propaganda in Twelfth-Century Spain", Speculum, 80, 2005, pp. 1134-1171; J. L. SENRA GABRIEL Y GALÁN, "La realidad material de la iglesia de San Martín de Frómista en el siglo XII: de 1066 a 1904", San Martín de Frómista, iparadigma o historicismo?, Valladolid, 2006, p. $37-68$, particularmente p. 54 , donde liga el piso superior del panteón con la iglesia fernandina y los modelos asturianos; J. WILLIAMS, "The Emergence of Spanish Romanesque Sculpture: A Century of Scholarship", Current Directions in Eleventh- and Twelfth-Century Sculpture Studies, Turnhout, 2010, 185-200 y M. V. HERRÁEZ ORTEGA, M. C. COSMEN ALONSO y M. VALDÉS FERNÁNDEZ, "La escultura de San Isidoro de León y su relación con otros talleres del Camino", De Arte, 12, 2013, pp. 41-58.
}

${ }^{25} \mathrm{El}$ autor negó las teorías de Boto en relación con la atribución de la planta excavada al templo de Alfonso $\mathrm{V}$, sobre cuyos cimientos de las naves elevaría Fernando I el suyo. Según Boto el templo fernandino debió continuar hacia el este, siendo de mayores dimensiones y
Dejando a un lado la controversia de la comitencia, datación y morfología arquitectónica de aquel edificio resulta absolutamente sintomático que, en lo relativo a su decoración, las referencias sean infinitamente menores, dispersas y, lo más preocupante, negadas. La mayor parte de los investigadores repitieron sin cesar que aquel edificio careció de cualquier ornato esculpido en piedra ${ }^{26}$.

Las siguientes páginas plantean algunas hipótesis en torno al conocimiento del ornato dentro de aquella vieja fábrica dedicada a San Juan Bautista y sólo a partir de 1063 y siendo el mismo edificio -no está de más recordarlo- dedicada a San Isidoro. Primeramente se realizarán algunas puntualizaciones sobre las obras orfebres que colmaron los altares de aquel templo para, finalmente, presentar dos piezas esculpidas en piedra, inéditas, que consideramos procedentes del edificio.

"EL ARCA CON SUS VARAS, SU TAPA Y EL VELO QUE LA CUBRE" (EX. 39: 12)

La profesora Etelvina Fernández es una de las investigadoras que con más detenimiento se ocupó de la prolija donación con la que los monarcas Fernando I y Sancha dotaron los altares de la desaparecida basílica de San Juan Bautista y San Pelayo. Acaeció el día 21 de diciembre del año 1063,

con una cabecera que, hoy por hoy, se desconoce. Cf. J. WILLIAMS, "San Isidoro Exposed: The Vicissitudes of Research in Romanesque Art", Journal of Medieval Iberian Studies, 3, 2011, pp. 93-116, en concreto, p. 95, nota 13.

${ }^{26}$ M. J. ÁLVAREZ GARCÍA, Románico rural de cabecera plana en el nordeste de León, León, 1990, p. 36; M. S. ÁLVAREZ MARTÍNEZ, "Valdediós y el arte de su tiempo", La época de Alfonso III y San Salvador de Valdediós, Oviedo, 1994, pp. 97-111; I. G. BANGO TORVISO, Alta Edad Media: de la tradición hispanovisigoda al románico, Madrid, 1989, p. 43; A. VIÑAYO GONZÁLEZ, León y Asturias: Oviedo, León, Zamora y Salamanca, Madrid, 1979, p. 31 y E. FERNÁNDEZ GONZÁLEZ, “Consideraciones generales sobre el románico en la provincia de León", Enciclopedia del Románico en Castilla y León. León, Aguilar de Campoo, 2002, pp. 35-52, concretamente, p. 39 . 
fecha excepcional en la que el templo cambió de advocación para honrar los restos de San Isidoro de Sevilla ${ }^{27}$.

El concienzudo análisis de la fuente documental efectuado por la autora pone de manifiesto la importancia del aparato litúrgico y, esto es absolutamente fundamental, la presencia de la imagen, dentro de cada una de las piezas de aquel severo templo. El texto, tomado de Sandoval, y tantas veces repetido, es el siguiente:

"Un frontal de oro puro, dignamente trabajado, con esmeraldas y zafiros; tres frontales de plata, uno para cada altar; tres coronas de oro, una de ellas seis alfas pendientes en el aro y colgante interior de alaures; la otra es de oro de anemmates, con cristales; la tercera, de oro, es la diadema de mi propia cabeza. Una arquita de cristal, recubierta de oro. Cruz de oro con vidrios y adornos de pedrería. Otra de marfil con la Imagen de Nuestro Señor Crucificado. Dos incensarios de oro con una naveta de oro. Otro incensario de plata de gran peso. Cáliz y patena de oro con cristales. Estolas de oro con los bordes de plata y labores de oro. Otra de plata con los bordes olivítrea. Una arqueta de marfil con labores de oro. Otras dos cajas de marfil con trabajos de plata, en una de ellas van encerradas tres cajitas de la misma materia. Dípticos de marfil esculpidos. Tres frontales bordados en oro $(\ldots)^{\prime 28}$.

No es necesaria perspicacia alguna para que, cuando menos, resulte sospechoso el hecho de que una dádiva que saturó los altares de un templo supuestamente tan pobre

${ }^{27}$ J. A. ESTÉVEZ SOLA, Crónica Najerense, Madrid, 2003, pp. 170-171. Cf.: E. FERNÁNDEZ GONZÁLEZ, "Imagen, devoción...", p. 174 e I. G. BANGO TORVISO, "La piedad de los reyes Fernando I y Sancha: Un tesoro sagrado que testimonia el proceso de renovación cultural hispana del siglo XI", Maravillas de la España medieval: Tesoro sagrado y monarquía, Valladolid, 2001, vol. I, pp. 223-227.

${ }^{28}$ P. SANDOVAL, Op.cit., p. 34. Un análisis de los términos más complejos del documento y su cotejo con las fuentes árabes en: E. FERNÁNDEZ GONZÁLEZ, “Imagen, devoción...", p. 176. sea, a todas luces, ilógicamente rica para ese pretendido contexto arquitectónico ${ }^{29}$.

La imagen y el ornato ocuparon un lugar referencial en aquel austero edificio, ya sobre los mismos altares o ya custodiados en el thesaurus ${ }^{30}$. A la vista del fastuoso despliegue visual de las piezas por todos conocidas el disloque arte-arquitectura debió ser tan impactante como, a mi juicio, poco creíble.

La que hoy llamamos arqueta de los marfiles reposó también en alguno de sus altares y de allí pasó al nuevo edificio románico: "A los dos lados de esta reja hay otras dos menores en alto y largo, así que dexan a la de en medio más levantada, y en la del lado de la Epístola está un arca de marfil con tanta guarnición de oro, que tiene más de metal que de hueso, y será de más que media vara de largo, y algo más en alto con la tumba. Está muy bien labrada para ser tan antigua, como lo muestran estos versos, que van escritos por lo alto en un freso (friso) de oro que rodea el arca. "Arcula Sanctorum micat haec sub honore duorum Baptistae Sancti Joannis, sive Pelagii. Ceu Rex Fernandus Reginaque Santia fieri jussit. Era Millena septena seu nonagena" ${ }^{\prime 31}$.

Aunque determinado sector de los estudiosos lo hayan obviado o prefieran olvidarlo, no existen argumentos para dudar

\footnotetext{
${ }^{29}$ Las recientes investigaciones de Seehausen señalan a las artes suntuarias como elementos fundamentales para conocer algunas de las ornamentaciones que debieron poseer las estructuras desaparecidas: F. SEEHAUSEN, "Baugeschichte als dynastisches Konstrukt. Die Bauphasen und ihre Interrelation mit der Kapitellskulptur von San Isidoro in León", Hispaniens Norden im 11. Jahrhundert. Christliche Kunst im Umbruch, Petersberg, 2009, pp. 198-209.

${ }^{30}$ No tenemos noticia de la morfología de los altares de aquella iglesia. No obstante, valórese la propuesta que defiende Boto sobre la inscripción de mármol empotrada en el brazo sur del transepto del edificio románico actual (ca. 1149). El investigador defiende su uso primitivo como ara de altar del templo fernandino: G. BOTO VARELA, “In Legionenssy...”, pp. 95-96.

${ }^{31}$ A. DE MORALES, Las antigüedades de las ciudades de España, Madrid, 1575, (ed. 1792), vol. 10, p. 63.
} 

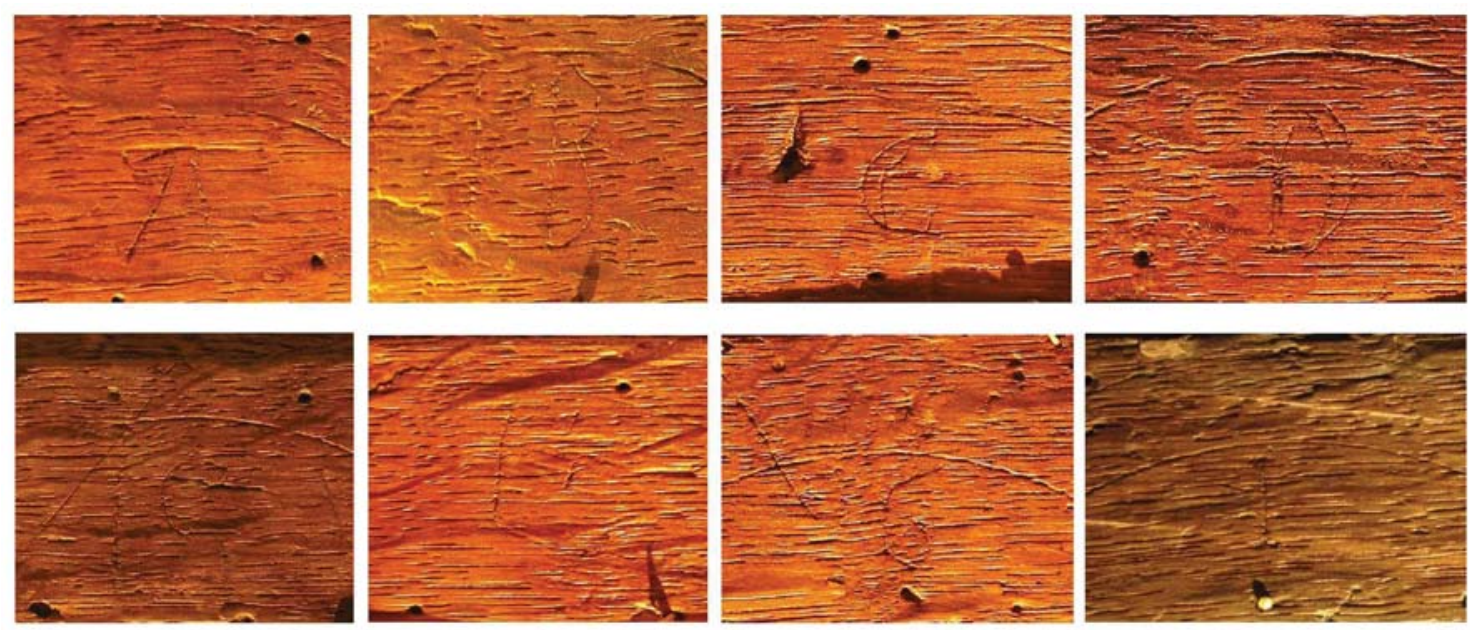

- Fig. 1. Letras guía. Arqueta de los marfiles, San Isidoro de León. Foto del autor.

de su cronología temprana: el año $1059^{32}$. En esa fecha el artífice evocó un ajedrezado, una solución muy frecuente en la escultura arquitectónica románica. Comparto con el profesor Isidro Bango la idea de que resulta imposible una explicación del motivo sin el conocimiento de la plástica monumental y su utilización en las cornisas del templo fernandino en una suerte de solución híbrida de planimetría asturiana y alzado románi$\mathrm{CO}^{33}$.

Hasta donde conozco un elemento ha pasado inadvertido en el estudio de la pieza. Los que facturaron el arca que contendría los restos del mártir Pelayo idearon una compleja estructura aurífera que, aunque perdida, fue milimétricamente pensada, antes de adosarla sobre el alma de madera. Aunque resulte lógico, ni la posición de las placas en marfil de los apóstoles, ni los enmarques en oro que se perdieron, fueron fruto del azar.

${ }^{32}$ D. PERRIER, “Die spanische Kleinkunst des 11 Jahrhunderts. Zur Klärung ihrer stilistischen Zusammenhänge im Hinblick auf die Frage ihrer Beziehungen zur Monumentalskulptur", Aachener Kunstblätter, 52, 1984, pp. 29-150 y L. WILLIAMS, The arts and crafts of older Spain, Londres, 1907, pp. 99-100.

33 Sobre el concepto "arquitectura híbrida": I. G. BANGO TORVISO, El Arte románico en Castilla y León, Madrid, 1997, p. 108. Seguido en: M. POZA YAGÜE, "Entre la tradición y la reforma: a vueltas de nuevo con las portadas de San Isidoro de León", Anuario del Departamento de Historia y Teoría del Arte, 15, 2003, pp. 9-28, p. 16 y A. GARCÍA MARTÍNEZ, “El Panteón...”, p. 12.
Hasta siete marcas hemos podido localizar esgrafiadas en la madera, siguiendo el alfabeto, y que señalarían la perfecta colocación de las planchas de oro, sin posibilidad de error o cambio alguno y con el fin de que, tanto ornamento arquitectónico -especialmente arquerías- como la inscripción, encajasen correctamente ${ }^{34}$ (Fig. 1).

Aquel templo fosilizador de la tradición asturiana y sin despliegue visual alguno contuvo entre sus muros, además, la doble arca isidoriana con un desarrollo iconográfico inaudito para el momento.

Obviando lo tedioso de repetirlo, considero que aún no se ha prestado especial atención a la descripción que de ella realizó Morales:

"El cuerpo del glorioso Doctor San Isidoro está tan rica y venerablemente colocado y guardado quanto reliquia lo puede estar en el mundo, porque está en medio del altar mayor detrás de una reja dorada de más de una vara de alto y dos en largo. El arca, que está detrás de esta reja, es de poco

\footnotetext{
${ }^{34}$ Son perfectamente visibles las letras A, B, C, D, E, F, G, I. Es posible pensar que las placas de oro albergaran las explanationes con los tituli apostólicos bajo arquerías de medio punto que volteaban sobre columnas completas, de ahí el necesario orden en su colocación siguiendo estas letras-guía. Se puede deducir igualmente que, repujada sobre el oro, iría la inscripción con la datación, en friso corrido, y cuyo orden consecutivo habría de seguirse inexorablemente.
} 
menos que dos varas en largo y media en alto, que está por la mayor parte cubierta de planchas de oro, y las demás de plata dorada, con los doce Apóstoles, y Dios Padre en medio, y con otras muchas imágenes en tondos esmaltadas. Hay así mismo por toda esta frontera muchos engastes de oro, grandes y pequeños, con piedras finas al parecer, aunque no preciosas. Los dos testeros, que se pueden bien ver, son cubiertos de una red muy menuda de plata dorada, harto bien labrada. La frontera de la arca se la dexó de oro el Rey (...) y figuras por la delantera de más que medio relieve, que parecen macizas. La trasera y el suelo también están cubiertas de planchas de plata lisa" 35 .

A pesar de que el mismo erudito ya señalaba una intervención sobre esta pieza tras los desperfectos y el robo perpetrado por el rey Alfonso de Aragón, aún debieron permanecer muchas de las originales en su lugar cuando Morales las vio: "llevó mucho de este oro, como mucho de Sahagún y otras iglesias: suplióse con plata dorada; y las planchas de oro y plata todas son gruesas y tienen lo labrado sobrepuesto por sí"36.

Un cobertor bordado en oro cubrió esta magna pieza. Sin duda un tema relevante y más difícil aún de analizar. Los frágiles textiles que hubo de poseer el tesoro de aquel edificio se perdieron en su gran mayoría, lo cual no es óbice para no tener en cuenta la potencia visual con la que decorarían altares, solerías y muros.

La misma Historia Silense anota datos sobre la riqueza visual de las telas, pues se indica que sobre la urna del hispalense "echó una cortina tejida con admirable labor sobre el sarcófago del confesor bienaventurado" ${ }^{37}$. Con toda razón, Etelvina Fernández plantea identificar el tejido hispanomusulmán que tapiza el interior del arca de San Isido-

\footnotetext{
${ }^{35}$ A. DE MORALES, Las antigüedades..., p. 61.

${ }^{36}$ Ibídem.

${ }^{37}$ Historia Silense..., p. 220.
}

ro con la mencionada en esta fuente ${ }^{38}$. Una noticia muy apreciada en los relatos modernos, donde ya Sandoval señalaba "poniendo pues el cuerpo de San Isidoro en una caxa de madera para poder llevarse de camino, el Rey Moro de Sevilla Benabet, dio un paño de seda de mucho valor" ${ }^{\prime \prime}$.

Resulta sorprendente que mientras Morales profundiza en detalle sobre el aspecto del arca exterior, maravillado por sus imágenes y suntuosidad, acto seguido se limita a una escueta mención del otro relicario que, a su vez, custodiaba esta arca: “Dentro de esta arca está otra menor de plata, sobre cuatro leones de lo mismo y no tiene ninguna cerradura, sino que está clavada con la plata" $^{40}$. Con este escueto párrafo cierra el viajero la descripción de esta pieza.

El rico programa del Génesis y las inscripciones de la tan celebrada arca de San Isidoro, por todos conocida y conservada en el Museo de la Real Colegiata, no debió ser nada comparable a la calidad y ostentosidad figurativa del arca exterior. Hoy, perdida esta pieza, poco se puede aportar, salvo reiterar, una vez más, la presencia de imágenes esculpidas en el amplísimo acervo visual que cobijó la desaparecida iglesia fernandina. Cultus et decor se aunaron aquí de una forma desconocida hasta el momento en la España medieval ${ }^{41}$.

Algunas puntualizaciones han de hacerse en relación con el relato de Morales. La presencia en el frontal del arca exterior de "doce Apóstoles, y Dios Padre en medio" apunta sobre el conocimiento de un esquema que, sólo años más tarde y en dependencia absoluta con el taller isidoriano de orfebrería, triunfaría en el Arca Santa de Oviedo, el frontal comandado por Gelmírez para Com-

\footnotetext{
${ }^{38}$ E. FERNÁNDEZ GONZÁLEZ, "Imagen, devoción...", p. 180.

${ }^{39}$ P. SANDOVAL, Op.cit., p. 32.

${ }^{40}$ Ibídem, p. 62.

${ }^{41} \mathrm{~S}$. DE BLAAUW, Cultus et decor: Liturgia e architettura nella Roma tardoantica e medievale, Ciudad del Vaticano, 1994, vol. I, pp. 23-49.
} 
postela o el del monasterio de Sahagún. No tengo dudas que, en estas secuencias, habrá de sopesarse en el futuro el importante lugar que debió ocupar la recientemente recuperada ara de Obona (Tineo, Asturias) ${ }^{42}$.

Finalmente, las "figuras por la delantera de más que medio relieve, que parecen macizas" no dejan lugar a dudas de que, también en el arca exterior de oro, se utilizaron los tan celebrados volúmenes craneales propios de la urna de plata que hoy poseemos y que los expertos han relacionado tradicionalmente con las artes del metal de Hildesheim.

Risco visionó las dos arcas en las mismas condiciones, pero, sorprendentemente, valoró más detenidamente el receptáculo interior: "Dentro de esta arca, que por la mayor parte está cubierta de planchas de oro, y otras de plata dorada con las figuras de los doce Apóstoles, y otras, se encierra otra arca menor, en que se guarda el cuerpo de san Isidoro, la qual está primorosamente labrada, y se sostiene sobre cuatro leones de plata. Vense en ella varias figuras e inscripciones, que contienen la historia del primer hombre, y otras varias imágenes, que la adornan por todos sus lados" ${ }^{\prime 3}$.

Además del ciclo del Génesis citado, quiero remarcar la presencia en esta pieza de los cuatro vivientes, bien a pesar de que actualmente solamente sobrevivan dos de aquellas figuras. Las fuentes revelan su colocación en el conjunto argénteo: “ay también un Toro, y una Águila, en que están representados los Evangelistas Juan, y San Lucas. El Toro está al lado del Evangelio, y al lado de la Epístola el Águila"44 (Fig. 2).

\footnotetext{
${ }^{42}$ Se analizan algunas de estas secuencias iconográficas en: J. A. MORÁIS MORÁN, “La imagen de la desaparecida ara de Obona (Asturias) en el contexto de la orfebrería románica astur-leonesa", Codex Aquilarensis, 29, 2013, pp. 223-250.

${ }^{43}$ M. RISCO, Op.cit., pp. 145-146.

${ }^{44} \mathrm{~J}$. MANZANO, Vida y portentosos milagros del glorioso San Isidro, Salamanca, 1732, pp. 379-381 y P. MINGOTE, Op. cit., p. 176.
}

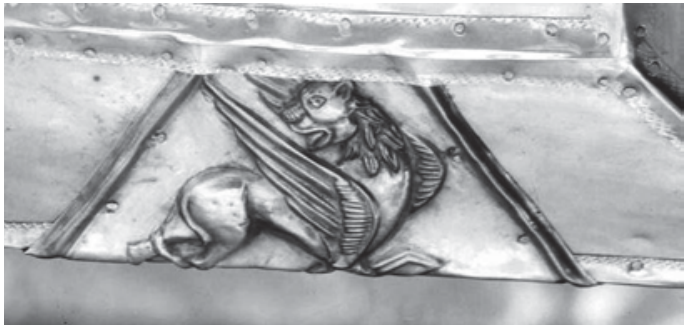

Fig. 2. Tetramorfos. Arca de San Isidoro, San Isidoro de León. Foto del autor.

En el marco 1059-1063 el Tetramorfos fue incluido en los ciclos visuales del templo fernandino y en dos de las piezas más importantes del templo: el arca del hispalense y la de San Pelayo ${ }^{45}$.

Los datos expuestos aquí, conocidos en su mayor parte, ofrecen una imagen extraordinariamente rica de las artes plásticas que aderezaron aquel espacio. La eclosión y exposición iconográfica documentada al menos desde el año 1059 no permiten, a nuestro juicio, continuar manteniendo que aquel templo carecía de decoración articulada, ni en sus objetos litúrgicos, evidentemente, ni en la decoración pétrea que albergó, tal y como pasamos a explicar.

“NOMBRÓ CANTEROS QUE LABRARAN LA PIEDRA PARA LA CONSTRUCCIÓN DEL TEMPLO DE DIOS" (1 CR. 22: 2)

El silencio que las fuentes han trasmitido sobre la ornamentación que ostentó la nueva construcción de los monarcas Fernando I y Sancha es el principal escollo para un análisis seguro. Limitándose éstas a señalar que la iglesia de San Juan Bautista fue construida en piedra $\mathrm{y}$, a tenor de los restos materiales exhumados en las actividades arqueológicas ya mencionadas, la crítica historiográfica no encontró suficientes argumentos para valorar el uso de la escultura arquitectónica dentro del edificio.

Pero las investigaciones han avanzado en los últimos años. Un reciente trabajo de la Dra. Etelvina Fernández ha permitido

\footnotetext{
${ }^{45}$ J. A. MORÁIS MORÁN, Op.cit., pp. 223-250.
} 
una datación más exacta y, sobre todo, una concreción sobre el origen de la célebre pila bautismal que custodia el actual recinto isidoriano $^{46}$. Con total lógica, la investigadora defendió su procedencia de la antigua basílica dedicada al Bautista, proponiendo una datación de mediados del siglo XI, acorde con los tiempos de Fernando I.

Incomprensiblemente, las fuentes modernas señalan, no obstante, que la pila bautismal procedía de otro templo. Conservada durante el siglo XIX junto a la tumba del constructor Pedro de Deustamben "junto al entierro del venerado artífice está la antiquísima pila bautismal, perteneciente a la parroquia de San Froilán y San Pedro que residió algún tiempo en aquella basílica, y cubierta por sus cuatro lados de relieves bizantinos (...) los caracteres dicen In nomine Domini Maria mater Dei et Johannes" ${ }^{\prime 7}$.

Por su parte, en 1872 Assas i Ereño supuso que la pieza había sido realizada "antes de reedificar el templo Fernando el Magno (...) acaso principios del siglo XI" $\mathrm{y}$, a la vez, desmiente las afirmaciones anteriores, defendiendo su factura para la iglesia del Precursor $^{48}$.

${ }^{46}$ E. FERNÁNDEZ GONZÁLEZ, "Hacia la renovación escultórica de la segunda mitad del siglo XI: Los ejemplos del sarcófago de San Martín de Dumio y de la pila bautismal de San Isidoro de León", De Arte, 6, 2007, pp. 5-36. Para Castiñeiras la pila continuó usándose en el edificio románico, en un contexto ritual bautismal: M. CASTIÑEIRAS GONZÁLEZ, “Topographie sacrée, liturgie pascale et reliques dans les grands centres de pèlerinage: Saint-Jacques-de-Compostelle, Saint-Isidore-de-Léon et Saint-Etienne-de-Ribas-de-Sil", Les Cahiers de Saint-Michel de Cuxa, 34, 2003, pp. 27-50. Véase también : A. FRANCO MATA, “Un vaciado de una pila bautismal de San Isidoro de León", Toletum, 54, 2007, pp. 167-176.

${ }^{47}$ J. M. QUADRADO, Op.cit., p. 342. Confirman la noticia, quizás inercialmente, otros autores, que señalan que la pila "procede en origen de la parroquial de San Pedro": P. MINGOTE, Op. cit., p. 177.

${ }^{48}$ M. DE ASSAS, "Pila bautismal de la iglesia de San Isidoro en la ciudad de León", Museo Español de Antigüedades, I, 1872, pp. 163-168, indica: "Si bien hay quien dice, sin probarlo, haber sido propiedad de la parroquia de San Froilan y San Pedro, que cuentan haber residido
La pertenencia de esta pieza al contexto fernandino arrojaría nuevas vías de estudio para el trabajo de los escultores en aquel edificio.

En tales hipótesis profundizaron, desde el año 2005, Horst Bredekamp y Frank Seehausen pero sus resultados, extrañamente, han tenido poca fortuna dentro de los estudios del románico isidoriano. Defensores de la unicidad del conjunto que adscriben al tiempo de Fernando I, volvieron, otra vez, sobre el asturianismo del templo de San Juan Bautista. Una novedad muy interesante ha pasado en cierta manera inadvertida a la hora de valorar las pruebas materiales que demostrarían que aquel edificio estuvo ornamentado escultóricamente. Para los autores, el canecillo conservado en el ángulo noroeste del templo ${ }^{49}$, es prueba suficiente para señalar que la escultura arquitectónica de la construcción desaparecida estuvo en plena consonancia con la del panteón. Dos fábricas coetáneas y, defienden, ornamentadas por los mismo talleres bajo la comitencia de Fernando $\mathrm{I}^{50}$ (Fig. 3).

La teoría ha sido bendecida por la máxima autoridad en la materia. John Williams no duda en considerar este canecillo como perteneciente "al voladizo más occidental de la nave lateral norte de la iglesia fernandina" 51 , mientras que otros autores, sin embargo, dudaron de esta hipótesis $\mathrm{y}$,

durante algún tiempo en la que llamaron de San Juan Bautista, es inadmisible que esta última iglesia, siendo también parroquial, careciese de pila, é inverosímil que la de San Froilan no se llevase la suya al volver á separarse ambas parroquias: debió, pues, labrarse para la iglesia del Precursor de Jesús".

${ }^{49}$ Visible hoy justo en la unión de la iglesia románica y la estructura superior erigida sobre el panteón (Cámara de doña Sancha).

${ }^{50}$ F. SEEHAUSEN, " Wege zum Heil - Betrachterlenkung...", p. 5.

${ }^{51}$ J. WILLIAMS, “San Isidoro exposed...", p. 105: "that potentially allows it to be identified as the westernmost corbel of the Fernandine northern aisle". 
entre ellos, Gerardo Boto, quién desliga esta escultura de la fábrica de Fernando $\mathrm{I}^{52}$.

Un análisis estilístico no deja duda alguna de su pertenencia a la misma cronología y taller que facturó la serie de capiteles del panteón

El canecillo, que aún debía permanecer enmascarado durante las campañas del investigador norteamericano, se ha convertido en prueba irrefutable para que los estudiosos germanos defiendan una comitencia unitaria del templo, el panteón y la tribuna superior por parte del monarca. En todo caso, y para los intereses de este trabajo, esta valiosa pieza, de confirmar su pertenencia al edificio fernandino, demostraría definitivamente la presencia de decoración esculpida en piedra en el alero del edificio ${ }^{53}$ y concretaría el origen del ajedrezado presente en la arqueta de los marfiles del año 1059.

En el marco teórico que defiende actualmente una progenie tolosana para las formas esculpidas en el panteón ${ }^{54}$, el profesor Williams relaciona el canecillo con otra pieza de modillones vueltos perteneciente a las primeras campañas decorativas de SaintSernin de Toulouse ${ }^{55}$.

Por nuestra parte queremos insistir en que los modelos que presenta la obra leonesa, con los modillones que se vuelven sobre sí mismos, tiene referentes hispanos lo suficientemente elocuentes como para continuar investigando sobre su datación y la construcción a la que perteneció. Uno de los canecillos conservados en el lapidario del mo-

\footnotetext{
${ }^{52}$ Considera que el muro sobre el que se asienta el modillón debe datarse en época de la infanta Urraca y no en el contexto constructivo fernandino. Cf.: G. BOTO VARELA, “In Legionenssy...", p. 119.

${ }^{53}$ J. WILLIAMS, “San Isidoro exposed...", p. 105.

${ }^{54} \mathrm{M}$. V. HERRAÉZ ORTEGA, C. COSMEN ALONSO y M. VALDÉS FERNÁNDEZ, Op.cit., p. 45.

${ }^{55}$ Especialmente una ménsula de la cabecera del edificio, publicada en dicho trabajo como fotografía de Therese Martin. Por su parte, Frank Seehausen establece paralelismos con una pieza de la catedral de Jaca. Cf.: J. WILLIAMS, “San Isidoro exposed...", pp. 105-108.
}

nasterio de Santo Domingo de Silos muestra, en nuestra opinión, una proximidad innegable y mayor con respecto a la escultura leonesa que cualquiera del corpus tolosano. La pieza en cuestión ha sido englobada por los expertos dentro del llamado grupo del "primer taller"56 (Fig. 3). En realidad, se trata de una escultura procedente de la desaparecida ermita de Santiago de Silos, ubicada en el cementerio del pueblo y que se desplomó en el año $1962^{57}$.

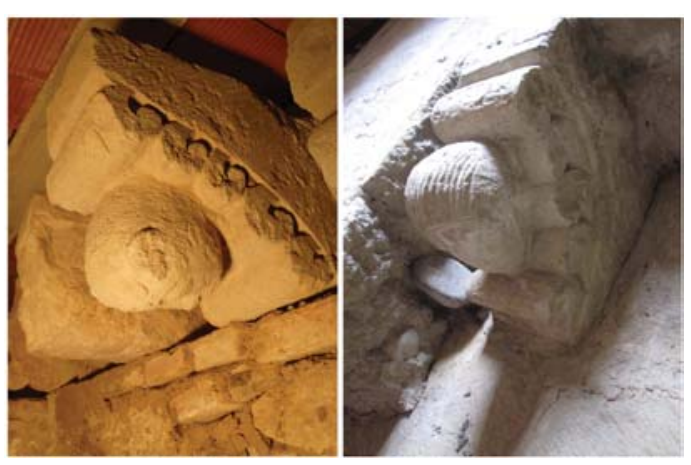

- Fig. 3. Canecillos. Santo Domingo de Silos, lapidario y San Isidoro de León. Foto del Museo y Claustro del Monasterio de Santo Domingo de Silos y del autor, respectivamente.

La conexión que proponemos entre los dos centros tiene, es sabido, su refrendo en ciertos acontecimientos históricos. Fernando I puso a Domingo Manso a la cabeza del monasterio silense en el año $1041^{58}$, asis-

${ }^{56} \mathrm{~J}$. YARZA LUACES, “Elementos formales del primer taller de Silos", El Románico en Silos. IX Centenario de la Consagración de la Iglesia y el claustro. 1088-1988, Burgos, 1990, pp. 105-147; C. DEL ÁLAMO MARTÍNEZ, Silos: cien años de historia (1880-1980), S. 1., 1983 y E. VALDEZ DEL ÁLAMO, Palace of the Mind. The Cloister of Silos and Spanish Sculpture of the Twelfth Century, Brepols, 2012, p. 38.

${ }^{57}$ W. M. WHITEHILL, "Tres iglesias del siglo XI en la provincia de Burgos", Boletín de la Academia de la Historia, CI, 1932, pp. 464-470 y J. PÉREZ CARMONA, Arquitectura y escultura románicas en la provincia de Burgos, Burgos, 1974, p. 169. Mi agradecimiento al Sr. Director del Museo y Claustro del Monasterio de Santo Domingo de Silos, D. Javier Martínez Ruiz, por su amable ayuda en la documentación y estudio de esta escultura.

${ }^{58}$ J. YARZA LUACES, “Historiografía artística silense", Silos. Un Milenio, Burgos, 2003, p. 16; J. L. SEN- 
tiendo este a la consagración del 1063, tras la recepción de las reliquias de San Isidoro en la capital leonesa ${ }^{59}$. Las relaciones entre los centros monásticos no debieron ser menores $y$ es en este contexto donde ha de estudiarse la relación entre la pieza leonesa y la silense, muy alejadas de las formas tolosanas ${ }^{60}$.

En contraste con la amplia aceptación del artículo publicado por Williams en el año 1973, nos sorprende la poca atención que se ha prestado a su última aportación, del año 2011. Insólitamente inadvertida para los investigadores ha pasado la atribución que el profesor norteamericano hace de un fragmento esculpido con vegetales, hoy custodiado en el claustro isidoriano y que, según escribe: "es posible que formara parte de un cancel de la iglesia de Fernando I" ${ }^{61}$. En mi opinión, no habrá de dudarse pues de una de las personas más autorizadas y que mejor conoce un edificio que excavó personalmente.

RA GABRIEL Y GALÁN, “El monasterio de Santo Domingo de Silos y la secuencia temporal de una singular arquitectura ornamentada", Siete Maravillas del Románico Español, Aguilar de Campoo, 2009, pp. 193-225, sobre el "primer taller" véanse pp. 213-216 e ÍDEM., "Between Rupture and Continuity: Romanesque Sculpture at the Monastery of Santo Domingo de Silos", Current Directions in Eleventh and Twelfth Century Sculpture Studies, Turnhout, 2010, pp. 141-167.

${ }^{59} \mathrm{G}$. BOTO VARELA, “Ora et memora. Il chiostro di San Domenico di Silos: castellum, paradisum, monumentum", Medioevo: Memoria e Immagine, Parma, 2009, pp. 105-128, en concreto, p. 45.

${ }^{60}$ No es lugar este para aludir a las diferentes posturas de los investigadores sobre el templo silense. Cf.: I. G. BANGO TORVISO, "Reformas monásticas y litúrgicas en relación con los edificios románicos de Santo Domingo de Silos", Los grandes monasterios benedictinos hispanos de época románica (1050-1200), Aguilar de Campoo, 2007, pp. 141-166 y J. L. SENRA GABRIEL Y GALÁN, "El monasterio de Santo Domingo de Silos y la secuencia...", pp. 193-225.

${ }^{61}$ J. WILLIAMS, "San Isidoro exposed...", p. 104: "is possible it was part of a chancel screen in Fernando's church". Por otra parte, la presencia de canceles en el templo solucionaría, parcialmente, la ausencia de hitos delimitadores del espacio litúrgico en el edificio que denunciaba Gerardo Boto.
Nuevamente reaparece la escultura en piedra como ornato de aquel templo sobrio.

El estudio detenido, no realizado hasta la fecha, del fragmento de cancel hallado por Williams en las excavaciones revela datos de enorme interés en torno a la escultura en piedra que ornó el templo. No tenemos dudas de que el fragmento de relieve exhumado debe datarse en la horquilla cronológica 1055-1063. La comparativa con una de las cenefas vegetales del arca de San Isidoro resulta sorprendente ${ }^{62}$ (Fig. 4). Se repite el ritmo compositivo, y sobre todo el uso en ambas del punteado profundo allí donde las hojas se envuelven en sí mismas. Por otra parte, mientras que en el relieve pétreo el final de las vainas se esquematiza mediante ceñidores, una solución parecida se aplicó sobre la plata, transformando dichos elementos en una representación ajustada de los nudos de los tallos herbáceos de los que brotan las palmetas. En todo caso, a primera vista la solución acabó por otorgar a estos detalles vegetales la forma de una abrazadera.
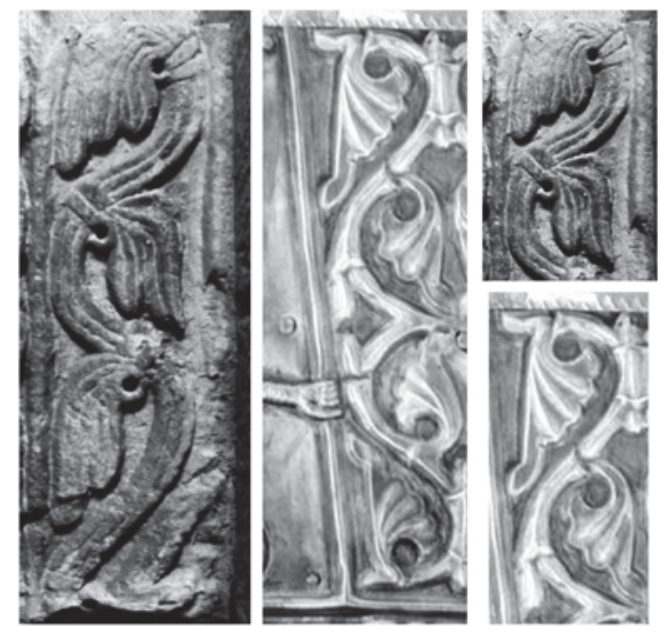

- Fig. 4. Fragmento de cancel y cenefa del arca de San Isidoro, San Isidoro de León. Foto del autor.

${ }^{62}$ Se trata de las dos cenefas que enmarcan la figura regia en la parte superior de la cubierta del arca. Otros autores ya defendieron contactos entre la escultura del panteón y la pieza argéntea. Véase: F. GARCÍA ROMO, La escultura del siglo XI: (Francia-España) y sus precedentes hispánicos, Madrid, 1973, p. 251. 
Con todo, aún es posible ir más allá en la restitución de las esculturas pétreas que decoraron el templo fernandino. Un vestigio escultórico conservado hoy en el claustro isidoriano, por su decoración y, especialmente por las medidas que posee, debió formar parte de ese destruido cancel $^{63}$. La decoración vegetal de esta pieza tiene un referente claro en la placa argéntea del arca de San Isidoro anexa a la figura del rey, mientras que el motivo floral hexafolio, a pesar de su carácter universal tiene referentes iguales en las piezas del tesoro isidoriano. Ello nos lleva a defender que ambos fragmentos formaron una pieza como la reproducimos y que, posiblemente, diferenció los espacios litúrgicos del templo de Fernando I entre los años 1050-1063 (Fig. 5).

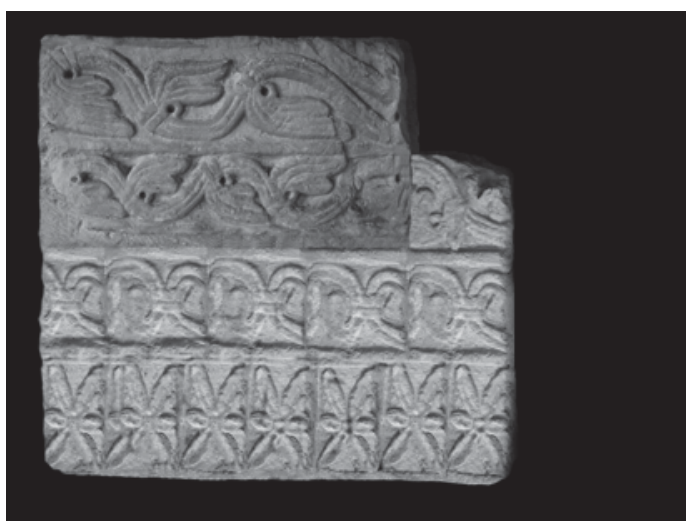

- Fig. 5. Reconstrucción de un cancel de la iglesia de Fernando I, San Juan Bautista de León. Foto del autor.

\section{"LOS CUATRO SERES VIVIENTES CAYERON DE RODILLAS DELANTE DEL CORDERO" (AP. 5: 8)}

Hace unos meses se publicó en la revista Románico una escueta nota donde se daba a conocer la existencia de una fotogra-

\footnotetext{
${ }^{63}$ León, Real Colegiata de San Isidoro, claustro, galería sur, $\mathrm{n}^{\mathrm{o}}$ de inventario 51135. Las dimensiones de la pieza que Williams considera un cancel y este fragmento nuevo que aportamos son pruebas definitivas, además del análisis pétreo y los motivos iconográficos, para defender que formaron parte de una misma escultura. Las medidas de ambas son: $18 \mathrm{~cm} \times 17 \mathrm{~cm}$.
}

fía conservada en el Instituto del Patrimonio Cultural de España que mostraba un relieve procedente de San Isidoro de León, hoy perdido, pero cuyo estudio creo conveniente desarrollar ahora ${ }^{64}$.

Facturado en caliza y de formato cuadrangular, muestra en su frente una iconografía que se articula en torno a la imagen de la cruz, en cuyo nudo se inscribió el Agnus Dei, enaltecido por el Tetramorfos, portando los libros y ubicado en los espacios generados por los travesaños. Mientras que el astil vertical aloja la imagen de dos figuras angélicas, en el brazo horizontal se dispusieron el Alfa y la Omega. La cruz se perfiló en todo su perímetro mediante sogueado (Fig. 6).

A pesar de que resulta complicado afirmar nada seguro a través de una fotografía, hemos podido calcular las medidas aproximadas del relieve ${ }^{65}$. La imagen permite asegurar el conocimiento de una depurada técnica escultórica, de volúmenes marcados, gran plasticidad y uso del trépano en algunos puntos. A pesar de su deterioro, un reborde plano rodea su perímetro, achaflanado en las esquinas e interrumpido, con ciertos aires naturalistas, por las alas de San Marcos y San Lucas o el plumaje de San Juan.

${ }^{64}$ Archivo del Instituto del Patrimonio Cultural de España, Fondo Moreno, nº de inventario 14062B, título "Cordero Místico con el Tetramorfos y Arcángeles". Se indica que la fotografía fue tomada entre 1893 y 1954. Cf.: J. A. MORÁIS MORÁN, “Edificaverunt lapideam: una escultura románica inédita en San Isidoro de León. Primeras elucubraciones en su fase inicial de estudio", Revista Románico, 17, 2013, pp. 8-15. La escultura no se localiza en la llamada "Sala Arqueológica" de la Real Colegiata. Tampoco la inventarió la Dra. Martin en su detallado estudio de tales vestigios. Cf.: T. MARTIN, "Una reconstrucción hipotética de la portada norte de la Real Colegiata de San Isidoro, León", Archivo Español de Arte, LXXXI, 324, 2008, pp. 357-378.

${ }^{65}$ La referencia para el cálculo la ofrecen los seis clavos del mueble de madera sobre el que fue fotografiada la escultura. De la medida de las cabezas de los citados clavos, $5 \mathrm{~mm}$. cada uno, hemos realizado un cálculo aproximativo que arroja unas medidas de $18,25 \mathrm{~cm}$ de largo y 15,37 cm de ancho. Este dato resulta importante para apoyar algunas hipótesis que plantearemos en las páginas siguientes. 


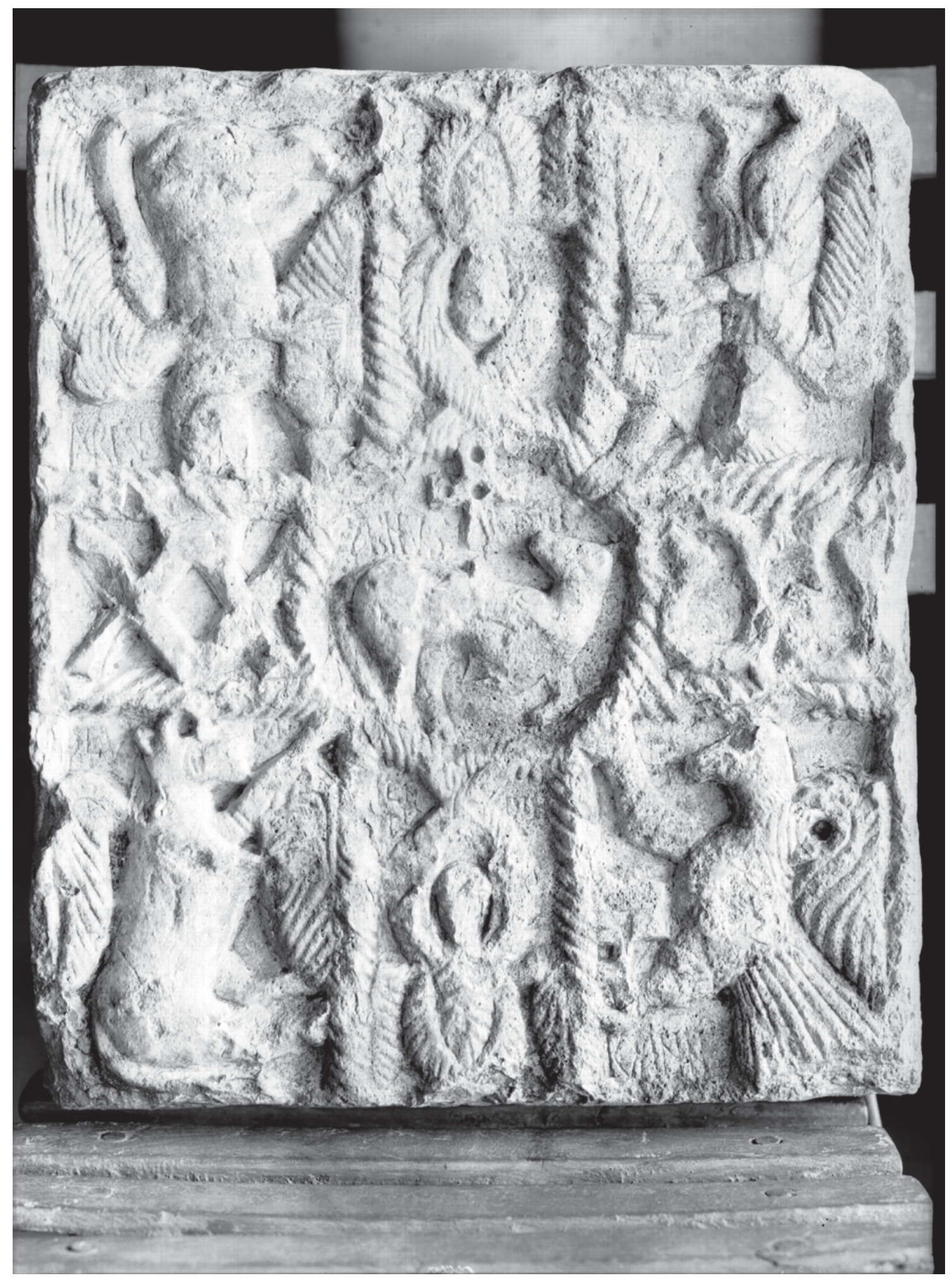

- Fig. 6. Relieve del Agnus Dei y el Tetramorfos, San Isidoro de León. Foto Instituto del Patrimonio Cultural de España, Fondo Moreno, noำ de inventario 14062B. 
Son precisamente las figuras evangélicas las que aportan mayor originalidad a la pieza dentro del corpus de esta iconografía en la Península Ibérica. Identificadas a través de sus explanationes intitulativas ${ }^{66}$, la epigrafía revela una escritura poco profunda, casi a modo de esgrafiado.

Estos tituli fueron ubicados en los espacios libres tras la labor escultórica, intuyendo entonces dos momentos en su factura, tal y como se ha documentado tantas veces en las artes escultóricas del románico, cuando la concepción del relieve y las inscripciones se realizaron, quizás, por manos diferentes ${ }^{67}$.

El Cordero, con la pata quebrada, porta una cruz de brazos decrecientes que han sido perforados, al igual que el nudo, con trépano. Es posible que tales orificios se rellenasen de pasta vítrea emulando la riqueza de los engastes, como en la miniatura de la cruz del Antifonario de la catedral León ${ }^{68}$. En todo caso se trataría de recursos propios de las artes del libro, tal y como ha señalado la Dra. Soledad Silva y Verástegui en relación con el Liber Comitis, fechado en el año 1073 $\mathrm{y}$, no ha de pasarse por alto, mostrando una cruz cuyo perímetro fue decorado íntegramente con sogueado, como en el relieve ${ }^{69}$.

Esta pequeña cruz que porta el Cordero fue acompañada, a cada lado, por la ins-

${ }^{6}$ E. MARTÍN LÓPEZ y V. GARCÍA LOBO, “La epigrafía medieval en España. Por una tipología de las inscripciones", VIII Jornadas Científicas sobre Documentación de la Hispania altomedieval, Madrid, 2009, pp. 185-213, concretamente, p. 194.

${ }^{67}$ Véase la interpretación de las inscripciones de la lauda de Ansúrez realizada por: A. MIGUÉLEZ CAVE$\mathrm{RO}$, “La Impaginatio como punto de partida: La relación entre texto e imagen en la cubierta del sarcófago de Alfonso Pérez procedente de Sahagún", Impaginatio en las inscripciones medievales, León, 2011, pp. 71-98.

${ }^{68}$ Archivo de la Catedral de León (en adelante ACL). Ms. Cod., 8, fol. 5 v.

${ }^{69}$ Real Academia de la Historia, Sig. Cod. 22, fol. 3v. Cf.: S. SILVA Y VERÁSTEGUI, “La miniatura en los códices de Silos", Silos. Un Milenio, Santo Domingo de Silos, 2003, pp. 211-254, particularmente, p. 240. cripción: "A(g)NVS DOMINI". A partir de este tondo central se distribuye, en la parte superior izquierda, la figura de "MARCVS". Resulta muy interesante la postura del evangelista en su forma animal, con el cuerpo de perfil, pasante, el rostro frontal, con atención detallada a la labor de las orejas puntiagudas y sustentando el libro con una de sus extremidades, mientras que con la otra ensalza el clípeo sogueado que forma el nudo de la cruz. Una postura esta que se repetirá en los restantes vivientes, con las alas desplegadas y trabajadas con delicadas ondas.

Al lado contrario se figuró a San Mateo con similares características. En el estado en el que nos ha llegado la fotografía que estudiamos resulta imposible concretar la existencia de inscripción alguna, salvo la posible "M" que se trazó sobre el libro que porta en sus manos.

En el extremo inverso de la pieza el águila de San Juan se aferra con las garras al sogueado. En los espacios sobrantes se esculpió el libro y la inscripción "IOANN". Es el único que muestra el cuerpo y las alas de perfil, a diferencia de los restantes evangelistas y es aquí donde el escultor vuelve a utilizar el trépano para remarcar su sinuosidad. De hecho, este tipo de cavidades o marcas circulares tiene paralelos exactos en la miniatura del siglo $X$, en particular, en la Biblia de la catedral de León. La descripción formal, tediosa y aparentemente improductiva, resulta fundamental en este caso. Será este manuscrito legionense el que ofrezca el modelo referencial que explique la posición frontal de San Lucas, Mateo y Marcos pues, en el códice, como en el relieve, solo San Juan aparece de perfil ${ }^{70}$.

Aún es posible leer, a renglón partido, "LV/CA", identificando al toro alado, con prominente hocico y marcada cornamenta, mientras que la cabeza y el cuerpo se muestran de

${ }^{70}$ ACL. Ms. Cod. 6, fols. 202, 209, 211 y 214. Resulta significativa la gran diferencia de posturas que muestra, al contrario, el Tetramorfos de la Biblia de San Isidoro. 
perfil, las alas se despliegan frontalmente, apoyando las pezuñas sobre el mismo sogueado.

La cuestión de las posturas y la ubicación de los epígrafes no es un tema menor. De ello se desprende, y no existe duda alguna sobre ello, que la escultura fue concebida para ser dispuesta de manera que la lectura del relieve fuera unidireccional, únicamente. Es decir, queda descartada su función vertical encajada sobre un muro o hipótesis parecida, pues resultaría ilógica la vista invertida de Marcos y Mateo. La correcta lectura de los epígrafes y la visión global de la composición atendió a una contemplación frontal, horizontal y, posiblemente, desde arriba, lo cual comienza a delatar la función que pudo tener este relieve.

Finalmente, las dos últimas figuras hacen eje compositivo con la imagen del Cordero. Dos presencias angélicas despliegan seis alas, dos sobre la cabeza, otras dos sobre el pecho y finalmente dos más en los laterales. Los dos alzan sus manos en actitud orante, siendo bien perceptibles en el ángel superior y con gesto que recuerda en todo caso al de la figura central, coetánea, del que se ha identificado como San Martin en la pieza funeraria de Dumio y sobre la que volveremos de seguido ${ }^{71}$. Mientras que el ángel de la parte superior, escoltado por Mateo y Marcos, no presenta restos de epígrafe alguno, el inferior que se acompaña de Lucas y Juan aún muestra vestigios muy desfigurados de su inscripción. Leemos "SER/NIS DOMN" en alusión, quizá, a los Serafines del Señor.

Para finalizar con el tema de las explanationes, no existen dudas de la tradición visigótica que impregna esta escritura, de módulo estrecho y alto, y donde predominan las formas rectilíneas. Se constata el uso de la $\mathrm{M}$ recta, la A con o sin travesaño y donde no es extraño que esta se inscriba dentro del espacio de otra letra, como es el caso de la palabra "MARCVS". De hecho, tal solución

${ }^{71}$ J. MORÍN DE PABLOS y R. BARROSO CABRERA, "Sarcófago de San Martín de Dumio", Dos Milenios en la Historia de España: año 1000, año 2000, Madrid, 2009, pp. 297-299. tiene paralelos cercanos en la misma Biblia visigótica de San Isidoro y el titulus de Marcos del fol. $12 \mathrm{r}^{72}$.

Igualmente, la R presenta el tercer trazo recto, la $\mathrm{N}$ un trazo trasversal que no llega a los extremos de los rectos $y$, finalmente, la $\mathrm{O}$ romboidal que puede considerarse otro de los signos inequívocos de una escritura visigótica, posiblemente del siglo $\mathrm{XI}^{73}$.

En torno a las fuentes bíblicas que inspiraron esta composición no parecen existir dudas: "Y miré y vi que en medio del trono y de los cuatro vivientes y de los ancianos había un Cordero, de pie, como sacrificado (...) Y cuando abrió el libro, los cuatro vivientes $(. .$.$) se postraron delante del Corde-$ ro (...) Miré y oí la voz de muchos ángeles alrededor del trono y de los vivientes (...) al Cordero alabanza, honor, gloria y poder por lo siglos de los siglos. Y los cuatro vivientes decían: "Amén" (Apocalipsis 5:6). "Los ángeles en torno al trono, los cuatro vivientes (...) proclaman: Digno es el Cordero, que ha sido degollado, de recibir el poder, la riqueza, la sabiduría, la fortaleza, el honor, la gloria y bendición" (Apocalipsis 5-12).

Es bien conocida la descripción de Ezequiel, I, I-28 sobre el Tetramorfos y el destacado lugar que ocupan en el relato las alas: "desplegadas hacia lo alto; dos se tocaban las del uno con las del otro, y dos de cada uno cubrían su cuerpo", dirá la fuente ${ }^{74}$. Un relato completado a través de Isaías 6, 1-7: "Había ante Él serafines, que cada uno tenía seis

${ }^{72}$ S. DOMÍNGUEZ SÁNCHEZ, "La escritura ordinaria de la Biblia visigótica de San Isidoro", Codex biblicus legionensis. Veinte estudios, León, 1999, pp. 111-126.

${ }^{73}$ Agradezco enormemente la ayuda prestada por la Dra. Encarnación Martín López (Universidad de León) en el tratamiento de los epígrafes, su lectura y contextualización cronológica. Cf.: V. GARCÍA LOBO y M. E. MARTÍN LÓPEZ, De epigrafía medieval: Introducción y álbum, León, 1995.

${ }^{74}$ Una compilación de este tipo de textos en: J. M. RODRÍGUEZ MONTAÑÉS, "Las visiones celestiales en la iconografía románica", Poder y sección de la imagen románica, Aguilar de Campoo, 2006, pp. 39-76 
alas: con dos se cubrían el rostro, y con dos se cubrían los pies, y con las otras dos volaban".

No es preciso realizar un mapa conceptual de este tema dentro de los ejemplos, innumerables, de la época medieval. René Crozet ya señaló en su día el importante papel de la Península Ibérica en la temprana utilización de los símbolos antropomórficos, aludiendo al sepulcro-relicario de San Martín de Dumio (s. XI) o el conocido capitel de Córdoba $^{75}$. Para el primero, no obstante, habrá que remarcar las certeras observaciones realizadas por Schlunk, pues defendió una inspiración en la ilustración miniada de los Beatos y, particularmente, en el de Fernando I, quién en el año 1064 tomó la ciudad lusa ${ }^{76}$. El dato resulta interesante para los intereses de este estudio.

Sin embargo, independientemente de las dos corrientes figurativas documentadas que los concebían en su efigie animal/zoocefálica o con cuerpo humano ${ }^{77}$, lo que es indudable es que el tema fue del todo apropiado para el ornato de sepulcros y relicarios ${ }^{78}$.

${ }^{75}$ R. CROZET, “Les représentations anthropo-zoomorphiques des évangélistes dans l'enluminure et dans la peinture murale aux époques carolingienne et romane", Cahiers de Civilisation Médiévale, 1958, I, pp. 182-187. Sobre Dumio: A. FERREIRO, "Sueves and Martin of Braga: Historiography and Future Research Projects", Suevos-Schwaben: das Königreich der Sueben auf der iberischen Halbinsel (411-585), Tübingen, 1998, pp. 37-62 y E. FERNÁNDEZ GONZÁLEZ, "Hacia la renovación...", p. 18-20. En el año 2004 se anunciaba la publicación de B. WINTERSTEIN, Ikonographie der Evangelisten im frühmittelalterlichen Hispanien, Georg-August-Universität Göttingen. El profesor A. Arbeiter, a quién desde aquí agradezco sus informaciones, me indicó que el texto se encuentra inédito aún.

${ }^{76}$ H. SCHLUNK, "Ein Sarkophag aus Dume im Museum in Braga", Madrider Mitteilungen, 9, 1968, pp. 424-458.

77 Sobre tal división: S. VIDAL ÁLVAREZ, "La transmisión iconográfica en la escultura hispánica de la antigüedad tardía. Vigencia y discontinuidad de modelos", Escultura decorativa y altomedieval en la Península Ibérica, Madrid, 2007, pp. 11-46, en concreto, p. 34.

${ }^{78}$ S. SILVA Y VERÁSTEGUI, "Los sepulcros de los santos: la piedad medieval, el sentido del decoro y el
La presencia zoomórfica de los evangelistas se rastrea fácilmente en la plástica monumental ravenante del mausoleo de Gala Placidia o en Santa Pudenziana de Roma (siglo $\mathrm{V})^{79}$ y tiene paralelos significativos en Mérida, donde se conserva la conocida placa del león alado de San Marcos ${ }^{80}$. No es preciso entrar aquí en las disputas sobre el origen de la imagen ${ }^{81}$, pero conviene señalar que durante el románico el Tetramorfos aparecerá normalmente con la Maiestas Domini dentro de las portadas monumentales (Moissac, San Trófimo de Arlès o el Pórtico de la Gloria) ${ }^{82}$ y hasta fechas tardías (portada sur de la catedral de León o el Sarmental de Burgos) ${ }^{83}$, así como en la pintura mural (Maderuelo) ${ }^{84}$. En todo caso, para las cuestiones iconográficas

ornato durante los siglos del románico", Edad Media. Revista de Historia, 10, 2009, pp. 93-129.

${ }^{79}$ I. GONZÁLEZ HERNANDO, "El Tetramorfo", Revista Digital de Iconografía Medieval, III, 5, 2011, pp. 6173; S. VIDAL ÁLVAREZ, Op. cit., p. 34 y A. O. POILPRE, Maiestas Domini. Une image de l'Église en Occident $\left(V^{e}-I X^{e}\right.$ siècles), París, 2005.

${ }^{80}$ Museo Nacional de Arte Romano de Mérida. Agradezco a Elisabeth Fragoso Pulido (MNAR) las informaciones ofrecidas sobre las piezas citadas. Cf.: M. WERNER, "On the Origin of Zooantropomorphic Evangelist Symbols: The Early Christian Background", Studies in Iconography, 10, 1986, pp. 1-35.

${ }^{81}$ R. CROZET, Op. cit.

82 Y. CHRISTE, Les grands portails romans, Ginebra, 1969, p. 32 y M. F FROMAGET, Maiestas Domini. Les Quatre Vivants de l'Apocalypse dans l'art, Turnhout, 2003.

${ }^{83}$ R. SÁNCHEZ AMEIJEIRAS, “La portada del Sarmental de la catedral de Burgos. Fuentes y fortuna", Materia, 1, 2001, pp. 161-198, concretamente, p. 187, donde analiza la postura del Tetramorfos burgalés y su dependencia con la escultura castellana del siglo XII.

${ }^{84} \mathrm{M}$. ANGHEBEN, “Théophanies absidales et liturgie eucharistique. L'exemple des peintures romanes de Catalogne et du nord des Pyrénées comportant un séraphin et un chérubin", Les fonts de la pintura romànica, Barcelona, 2008, pp. 57-96; F. VAN DER MEER, “La théophanie sans voile. Celui qui est assis sur le trône", Maiestas Domini. Théophanies de l'Apocalypse dans l'art Chrétien, Roma-París, 1938, pp. 220-399; E. MANSO y M. A. SÁNCHEZ-RUBIO, "Orígenes y fuentes de la iconografía del Tetramorfos en la pintura románica castellano-leonesa", Cuadernos de Arte e Iconografía, tomo II, 3, 1989, pp. 110-116 e I. GONZÁLEZ HERNANDO, Op. cit. 
más profundas, reemitimos a los estudios de Marcello Angheben, quién mejor ha tratado recientemente estos temas en relación con el arte románico hispano ${ }^{85}$.

Pero la ascendencia del relieve isidoriano es otra. Como en la vieja tradición paleocristiana los cuatro vivientes flanquean la imagen de la Cruz y el Agnus Dei. Frente a la novedosa inclusión de la Maiestas en los murales del panteón, ningún recuerdo de esta tradición se manifiesta en el relieve. Al contrario, el mismo horizonte cronológico y genealogía de símbolo comparte con el Beato de Fernando I, hecho que nuevamente nos lleva hacia la ilustración del libro ${ }^{86}$.

La presencia de los dos serafines y la disposición de las alas tienen referentes abundantes en el arte medieval hispano, con ejemplos en la pintura mural ${ }^{87}$ y la escultura en piedra de Cataluña, con un serafín, el Agnus Dei y la cruz del relieve conservado en Nueva York y datado en torno al $1140^{88}$. Pero con todo, insistimos, la disposición de las alas sirviendo de base al clípeo utilizada en la composición leonesa tiene referentes librarios similares, por ejemplo, al Sacramentario de Metz ${ }^{89}$.

Como es sabido los serafines fueron incluidos tradicionalmente en las cortes angélicas y englobados por los teólogos en la triada superior, junto con los Querubines y los $\operatorname{Tronos}^{90}$. Así, si las fuentes bíblicas ex-

${ }^{85}$ M. ANGHEBEN, Op.cit., pp. 57-96.

${ }^{86}$ Biblioteca Nacional de España (en adelante BNE), Ms. Vit. 14-2, fol. 116v. Cf.: I. GONZÁLEZ HERNANDO, Op. cit., p. 71.

${ }^{87}$ Remito al trabajo del Dr. Angheben, donde se analiza detalladamente las diferentes tipologías de alas en los serafines. Hago notar que en el relieve de San Isidoro son las seis iguales. Cf.: M. ANGHEBEN, Op.cit., p. 59.

${ }^{88}$ Metropolitan Museum of Art. № de inventario 25.120 .574

${ }^{89}$ Bibliothèque nationale de France, Ms. lat. 1141, f. 5. Cf.: M. ANGHEBEN, Op.cit., pp. 57-96.

90 G. PEERS, Subtle Bodies: Representing Angels in Byzantium, California, 2001, p. 24. plican primeramente su inclusión en esta obra $^{91}$, no ha de pasarse por alto la relevancia que para el contexto isidoriano y asturleonés en general tendría la comunión de las figuras angélicas y la imagen de la cruz. Será precisamente la Crónica Silense, compuesta en San Isidoro de León, el lugar en el que primeramente surja la mítica leyenda de tradición hagiropoetai de la cruz de los Ángeles y su factura angelical ${ }^{92}$, narración que tan sólo ponía por escrito una larga trayectoria visual anterior al año mil donde las cortes angélicas exaltaban la imagen de la $\mathrm{cruz}^{93}$. Con la llegada de la undécima centuria los humildes ángeles aparecerán custodiándola y postrándose ante ella, especialmente en las estaurotecas, arquetas y diverso mobiliario litúrgico ${ }^{94}$. Así fueron esculpidos en el altar románico de San Cataldo (Sicilia) vinculado al desarrollo litúrgico de la eucaristía ${ }^{95}$.

El aparente carácter arquetípico de la iconografía que muestra este relieve induciría a una fácil equiparación con otras piezas del entorno leonés. Podría concluirse que la conjunción del Agnus Dei, el Tetramorfos y

${ }^{91}$ Y. CHRISTE, L'Apocalypse de Jean. Sens et développements de ses visions synthétiques, Paris, 1996.

${ }^{92}$ G. CAVERO DOMÍNGUEZ, "El discurso de la Crónica silense...".

${ }^{93}$ R. ALONSO ÁLVAREZ, "El origen de las leyendas de la Cruz de los Ángeles y la Cruz de la Victoria (catedral de Oviedo): cruces gemmatx al servicio de la propaganda episcopal", Territorio, Sociedad y Poder, 5, 2010, pp. 23-33 y C. CID PRIEGO, “¿Existió miniatura prerrománica asturiana?", Liño, 1, 1980, pp. 107-142. Sobre el origen clásico del tema: T. MARTIN, "The Development of Winged Angels in Early Christian Art", Espacio, Tiempo y Forma, Serie VII, Historia del Arte, 14, 2001, pp. 11-19 y P. FAURE, “Les cieux ouverts. Les anges et leurs images dans le christianisme médiéval $\left(\mathrm{XI}^{\mathrm{e}}-\mathrm{XIII}{ }^{\mathrm{e}}\right.$ siècles)", Les Cahiers du Centre de Recherches Historiques, 13, 1994, consultado el 25 de enero de 2014 URL: http:// ccrh.revues.org/2699

${ }^{94}$ R. ALONSO ÁLVAREZ, Op.cit., p. 30.

${ }^{95}$ M. ANGHEBEN, Op.cit., p. 69. Se estudia la presencia de serafines/querubines en el frente del Altar Ratchis, el antipendio de Carlos El Calvo de Saint-Denis o las placas del deambulatorio de Saint-Sernin de Toulouse. Para las teofanías catalanas concluye unos orígenes romanos altomedievales $\mathrm{u}$ orientales. 
las cortes angélicas se encontraba perfectamente articulada antes del año mil ornando la arqueta de San Genadio de la catedral de Astorga $^{96}$. En el mismo marco cronológico podría añadirse también la arqueta realizada en chapas de latón sobre alma de madera del templo de Nuestra Señora de Peñalba (La Rioja) $)^{97}$ y la ruda arqueta del monasterio viejo de San Juan de la Peña, con Tetramorfos y ángeles (ca. 950) ${ }^{98}$.

Ciertos aspectos formales permiten equiparaciones generales pero no ha de olvidarse que, iconográficamente, existen contrastes importantes. A diferencia del relieve de San Isidoro, en la arqueta asturicense fueron "ANGELVS" los representados, tomando especial relevancia Gabriel, frente a los serafines de la escultura isidoriana. No se trata de un tema menor y los matices interpretativos son importantes ${ }^{99}$.

A ello sumamos la pérdida en la pieza astorgana de los símbolos de San Mateo y San Marcos. En todo caso, Lucas fue materializado en una versión mixta, zoo-antropomorfa que lo separa del relieve de San Isidoro. De hecho, la figuración semihumana de la arqueta de San Genadio será la que mayor éxito tendría en las artes anteriores al año mil y, como señaló Schlunk, con ejemplos tan importantes como los de las basas de San Miguel de Lillo y la caja de las Ágatas ${ }^{100}$.

96 J. ADHÉMAR, Influences antiques dans l'art du moyen âge français: recherches sur les sources et les thèmes d'inspiration, Londres, 1939, p. 167, comparaba la pieza asturicense con los sarcófagos merovingios.

${ }^{97}$ A. ARBEITER, "Chapas decoradas de un posible relicario altomedieval riojano", Arte Medieval en la Rioja. Prerrománico y Románico, Logroño, 2002, pp. 95-108.

${ }^{98}$ F. GALTIER MARTÍ, “Lipsanoteca del Monasterio Viejo de San Juan de la Peña", Sancho el Mayor y sus herederos: el linaje que europeizó los reinos hispanos, Pamplona, 2006, ficha 158, pp. 529-531.

99 M. ANGHEBEN, "Les théophanies composites des arcs absidaux et la liturgie eucharistique", Cahiers de civilisation médiévale, 54, 2011, pp. 113-142.

${ }^{100}$ H. SCHLUNK, “Observaciones en torno a la miniatura visigoda", Archivo Español de Arte, 71, 1945, pp. 241-65.
La tradición del Tetramorfos zoo-antropomórfico continuará en obras de mayor empaque para el arte románico. Aún en el Beato de Fernando I, obra posiblemente encargada hacia el año $1047^{101}$, persiste la imagen mixta donde los vivientes despliegan sus alas, vestidos con túnicas y sobre las ruedas de fuego. Así se muestran en la página de diseño cupuliforme de la visión del Cordero ${ }^{102}$.

Sin embargo, los modelos para el relieve que estudiamos son otros ${ }^{103}$. Aquí los escultores recurrieron al tipo más antiguo que se ha documentando en la Península Ibérica y donde el Tetramorfos se presentaba en su forma completamente animal. Así lo vimos, ya se ha indicado, en la placa de San Marcos de Mérida y en los ejemplos toledanos analizados por la Dra. María Cruz Villalón ${ }^{104}$. Y, finalmente, frente a los restantes manuscritos citados ha de remarcarse que será la llama-

${ }^{101}$ BNE, Vit. 14-2. Cf.: J. WILLIAMS, The Illustrated Beatus: A Corpus of the Illustrations of the Commentary, Londres, 1998, vol. III, pp. 34-40; ÍDEM, “Fernando I and Alfonso VI as Patrons of the Arts", Anales de historia del arte, № Extra 2, 2011, pp. 413-435, en concreto, p. 413 y J. YARZA LUACES, "La ilustración del Beato de Fernando y Sancha", Beato de Liébana. Beato de Fernando I y doña Sancha, Barcelona, 1994, pp. 60-90.

${ }^{102}$ BNE, Vit. 14-2, fol. 116v. Para otros ejemplos donde el Tetramorfos es híbrido: Fols. 7v, 8r. y v., 9r. y v. y 10r. Cf.: J. YARZA LUACES, “Las miniaturas...", p. 156. El esquema cupular se adaptó a espacios cuadrangulares, al menos desde el siglo IV, en San Vital de Rávena, donde el Agnus Dei triunfante en clípeo es enaltecido por los ángeles que lo elevan con sus manos.

${ }^{103}$ En todo caso el recuerdo de la plástica del siglo $X$ aún persiste tal y como se señala en: J. A. MORÁIS MORÁN, “Edificaverunt...", p. 11.

${ }^{104}$ En Mérida, además del ejemplar de San Marcos, apareció en el área de Morería una escultura que se ha identificado con San Mateo y que la profesora Cruz Villalón data entre el siglo IV y V. Cf.: M. CRUZ VILLALÓN, "La escultura paleocristiana y altomedieval en Extremadura", Repertorio de arquitectura cristiana en Extremadura: época tardoantigua. Anejos del Archivo Español de Arqueología, Madrid, 2003, pp. 253-270, en particular, p. 255; ÍDEM, Mérida visigoda: la escultura arquitectónica y litúrgica, Badajoz, 1985, p. 201; A. ARBEITER, Op. cit., p. 104 y R. BARROSO CABRERA y J. MORÍN DE PABLOS, Regia Sedes Toletana, El Toledo visigodo a través de su escultura monumental Toledo, 2007, p. 40. 
da Biblia visigótico mozárabe o primera de San Isidoro (ca. 960) la que incluya una página donde los vivientes se concibieron en su forma completamente animal ${ }^{105}$ (Fig. 7). Si la irrupción del tipo más reciente que concebía a los vivientes en su visión zoo-cefálica aún habría de esperar unas décadas para materializarse monumentalmente en las pinturas del panteón real, todo parece indicar que la fuente para el relieve está en el citado códice ${ }^{106}$.

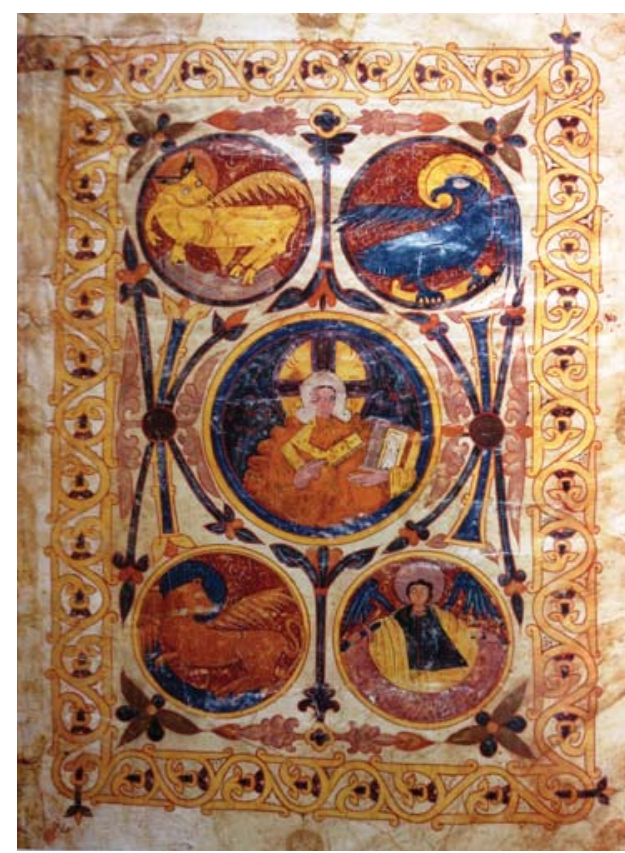

- Fig. 7. Archivo Real Colegiata de San Isidoro. Biblia del 960. Cod. 2, fol. 2r.

En todo caso conviene señalar que, a mediados del siglo XI, ciertos esquemas figurativos presentes en este relieve ornaban las mejores piezas del ajuar litúrgico del templo fernandino. Resultan obvias las similitudes conceptuales que la escultura pé-

${ }^{105}$ Archivo Real Colegiata de San Isidoro, Cod. 2, fol. 2r. Cf.: E. FERNÁNDEZ GONZÁLEZ, “Aproximación a la estética de las miniaturas del Códice", Codex biblicus Legionensis: veinte estudios, León, 1999, pp. 161-174 y J. WILLIAMS, "Orígenes de las miniaturas de la Biblia de San Isidoro", Ibídem, pp. 143-160, en concreto p. 147.

${ }^{106}$ En la llamada Segunda Biblia de San Isidoro nótese que el Tetramorfos del canon de Eusebio ya presenta cuerpo humano y cabeza animal, como en los murales del panteón. trea presenta con la arqueta de los marfiles, recordémoslo, datada en 1059. La parte superior de su cubierta aún conserva la placa donde el Agnus Dei se acompaña del Tetramorfos en su forma animal, remarcando su dimensión litúrgica, especialmente a partir de la inclusión de los serafines ${ }^{107}$ (Fig. 8).

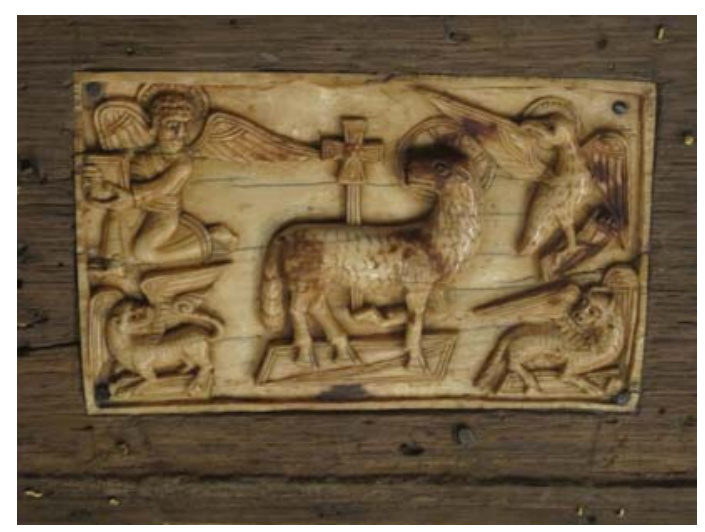

- Fig. 8. Tetramorfos y Agnus Dei. Arqueta de los marfiles, San Isidoro de León. Foto del autor.

En nuestra opinión resulta muy relevante que haya sido en ese marco cronológico transcurrido entre los años $1059 \mathrm{y}$ 1063 cuando la imagen del Tetramorfos se materializara, siguiendo el prototipo más antiguo documentado en la Península Ibérica, en otras piezas del tesoro isidoriano. La urna del santo hispalense aún conserva los vestigios de San Marcos y San Lucas, nuevamente como simples animales alados. Finalmente, tanto el reverso del crucifijo donado por Fernando I como la placa de la Traditio Legis del Louvre muestran idénticas soluciones ${ }^{108}$.

Todo ello nos lleva, finalmente, a concluir una asiduidad en la utilización de la imagen zoomórfica de los vivientes a mediados del siglo XI, fecha en la que, anunciamos, creemos que fue realizada esta escultura.

\footnotetext{
${ }^{107}$ A. FRANCO MATA, “El tesoro de San Isidoro y la monarquía leonesa", Boletín del Museo Arqueológico Nacional, IX, 1991, pp. 35-67.

${ }^{108}$ P. LASCO, Ars sacra: 800-1200, New Haven, 1994, p. 258 y J. WILLIAMS, "Fernando I and Alfonso...", p. 426.
} 
En todo caso, y ya desde una vertiente estilística, ciertas soluciones del relieve remiten indudablemente a la pila bautismal de San Isidoro, recientemente datada a mediados de la undécima centuria, en consonancia con el sepulcro de San Martín de Dumio y, como ya he señalado, proveniente del antiguo templo de San Juan Bautista (ca. 1055-1063).

La utilización en esta obra de un sogueado de factura similar al relieve del $A g$ nus Dei podría delatar unos mismos orígenes técnicos para ambas piezas y en la misma dirección apuntan las concomitancias epigráficas $^{109}$ (Fig. 9).

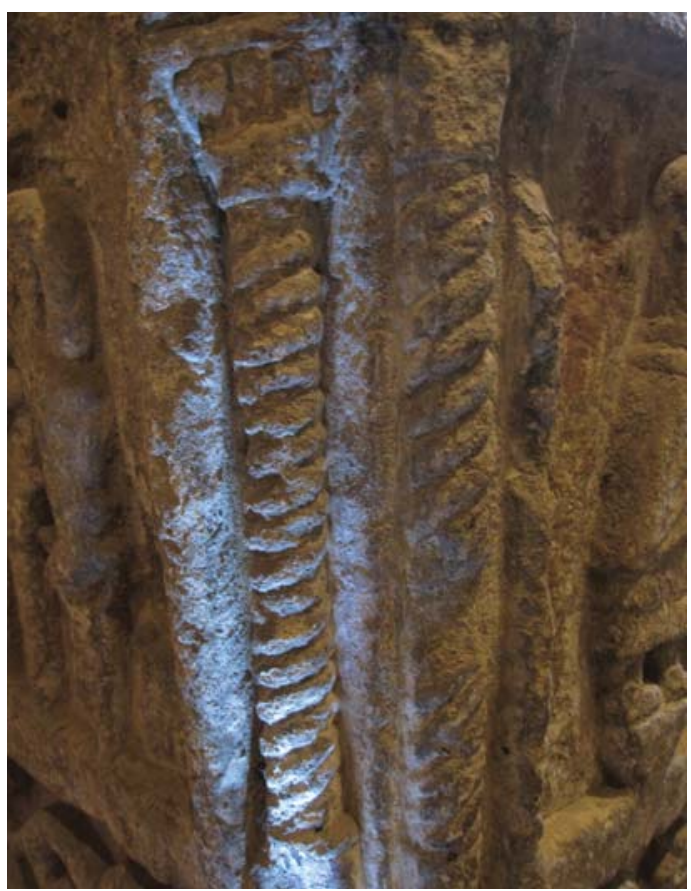

- Fig. 9. Sogueado. Pila bautismal, San Isidoro de León. Foto del autor.

En relación con la función que el relieve pudo tener, habrán de recuperarse las informaciones relativas a sus medidas. Según los cálculos, ya expuestos, la pieza debió medir 18,25 cm de largo y 15,37 cm de ancho. Cifras en todo caso que resultan fundamentales para apoyar los siguientes argumentos.

En el mismo lapidario isidoriano hemos hallado dos interesantes piezas factura-

\footnotetext{
${ }^{109}$ J. A. MORÁIS MORÁN, “Edificaverunt...”, p. 11.
}

das en caliza, de formato cúbico, horadadas en su interior con gran profundidad y de bordes achaflanados. Las medidas de una de ellas ${ }^{110}$, hacen factible que, en algún momento, hubiera compuesto, junto el relieve que analizamos, el cuerpo y la cubierta de un relicario pétreo (Fig. 10).
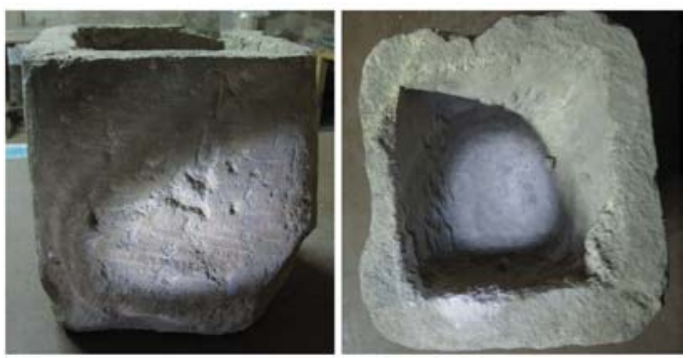

- Fig. 10. Arqueta pétrea. San Isidoro de León, lapidario. Foto del autor.

La función de lipsanoteca o relicario lítico no debe descartarse en ningún caso a juzgar por los casos altomedievales que conservamos. Por su formato, la caja leonesa recuerda la aparecida en el suelo del ábside de la iglesia de Sant Andreu de Prat del Campanar (Andorra). Del siglo $\mathrm{X}$ nos llegaron la lipsanoteca de Bíbiles (Huesca) ${ }^{111}$ y la de Santa María de Lillet (Berguedá, Cataluña), realizada en alabastro ${ }^{112}$. Aún debe citarse la de Vivers (Rosellón), procedente de San Miquel $^{113}$.

\footnotetext{
${ }^{110}$ Real Colegiata de San Isidoro. Lapidario. Sin catalogar. La primera de las piezas, en peor estado, mide $18 \times 17 \mathrm{~cm}, 3 \mathrm{~cm}$ de grosor y $11 \mathrm{~cm}$ de profundidad. La segunda, mejor conservada, mide $27 \times 26 \mathrm{~cm}$ en sus perfiles exteriores, $20 \times 20$ en su perfil interior y $3 \mathrm{~cm}$ de espesor. Creemos que las medidas de la segunda imposibilitan una relación con el relieve.

${ }^{111}$ Museo Diocesano de Barbastro. Cf.: I. G. BANGO TORVISO, "Lipsanoteca de San Salvador de Bibiles (I, II)", Sancho el Mayor y sus herederos: el linaje que europeizó los reinos hispanos, Pamplona, 2006, fichas 160-161, pp. 537-539.

${ }^{112}$ Museu Comarcal de Manresa. Cf.: M. SAURA, "Lipsanoteca de Lillet", Cataluña en la época carolingia: arte y cultura antes del románico (siglos IX y X), Barcelona, 1999, ficha 137, p. 388.

${ }^{113}$ M. SAURA, "Lipsanoteca de Vivers", Cataluña en la época carolingia: arte y cultura antes del románico (siglos IX y X), Barcelona, 1999, ficha 136, p. 387.
} 
En el ámbito europeo resulta fácil rastrear ejemplos de relicarios pétreos que además se ornaron con los símbolos criptomórficos. La cruz o el crismón fueron los más frecuentes $\mathrm{y}$, a este respecto, baste citar el procedente de la abadía de Saint-Germain de Auxerre, equiparable tanto en su factura como en su formato cúbico ${ }^{114}$.

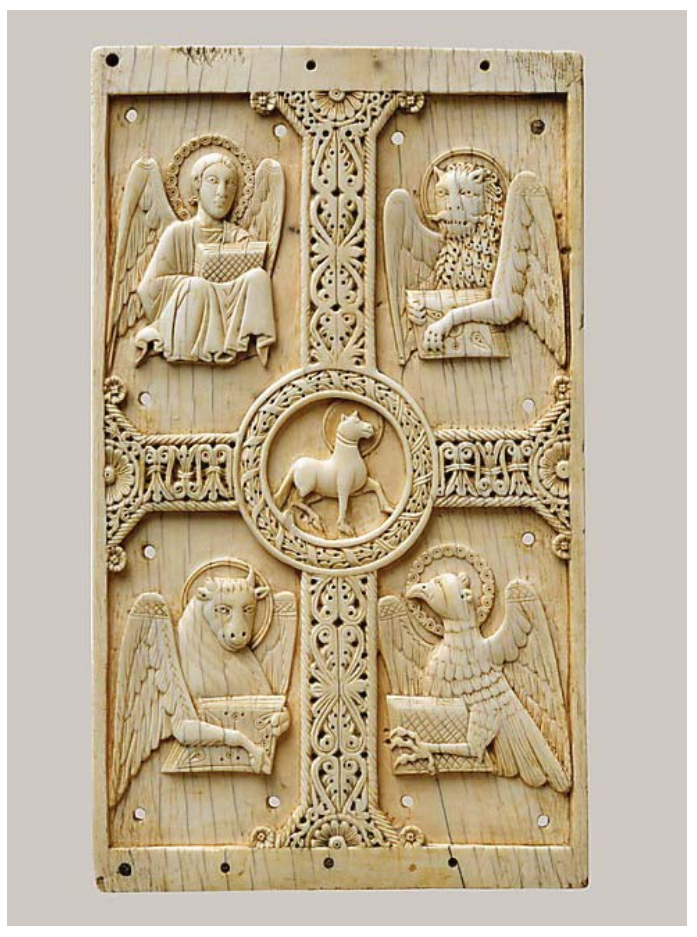

- Fig. 11. Placa de marfil. Metropolitan Museum of Art. № de inventario 17.190.38. Foto del autor.

En realidad, y cuando la distribución de las imágenes se vertebraba en torno a la cruz o el crismón, todas estas piezas en materiales más pobres repetirían los modelos de prestigio realizados en marfil. La placa ebúrnea procedente de Benevento y datada en el año 1050 ofrece uno de los paralelismos compositivos, y cronológicos, más cercanos al relieve de León ${ }^{115}$ (Fig. 11).

${ }^{114}$ P. GEORGE, "Définition et fonction d'un trésor d'église", Bulletin du centre d'études médiévales d'Auxerre, consultado el 27 de enero de 2014: URL: http://cem.revues.org/719.

${ }^{115}$ Metropolitan Museum of Art. № de inventario 17.190.38. Cf.: W. WIXOM, "Plaque with Agnus Dei on a Cross between Emblems of the Four Evangelists", Heilb-
La dificultad para encontrar relicarios pétreos de época románica se explica en el caso hispano a través, resulta fundamental, del Concilio de Coyanza celebrado en el año 1055 ${ }^{116}$. Como recientemente analizó Isidro Bango, tal acontecimiento fue de gran relevancia para las artes durante el reinado de Fernando I y Sancha ${ }^{117}$, convirtiéndose en causa fundamental de la renovación de los materiales con los que, hasta esa fecha, venían realizándose los relicarios. No es preciso insistir en la paulatina sustitución de los viejos facturados en madera, piedra o estuco por otros de mayor entidad realizados en oro, plata y marfil.

Para el caso de San Isidoro, aún es posible comprender la supervivencia de algunas de estas piezas pétreas, ya fuese por su deseo de preservarlas por las imágenes sagradas que contenían o, en la mayor parte de los casos, por su reutilización encastradas en los muros de las nuevas construcciones. Este es el caso de la caja lítica que ligamos a la cubierta, aparecida en el año 1914 durante las labores de restauración y reempleada en la galería románica anexada al norte del templo de Fernando I, tal y como revela la documentación ${ }^{118}$.

runn Timeline of Art History, New York, 2000, consultado el 6 de febrero de 2014: URL: http://www.metmuseum. org/toah/works-of-art/17.190.38.

${ }^{116}$ A. GARCÍA GALLO, "El concilio de Coyanza", Anuario de Historia del Derecho Español, 20, 1950, pp. 275633.

${ }^{117}$ I. G. BANGO TORVISO, "La renovación del tesoro sagrado a partir del concilio de Coyanza y el taller real de orfebrería de León. El Arca Santa de Oviedo (1072)", Anales de Historia del Arte. Volumen Extraordinario, 2, 2011, pp. 11-67.

${ }^{118}$ Este último dato sobre su reutilización como material de construcción y el lugar y la fecha en la que fue encontrada lo tomamos de una nota manuscrita sobre papel y adherida a la parte baja de la pieza donde se indicaba: "Parecieron 1o pilastra del claustro interior 5 enero 1914". Así lo comprobamos en noviembre de 2013 dentro del lapidario isidoriano. Desde luego, si fue encastrada durante la construcción de la galería románica ello nos ofrece, nuevamente, argumentos que apoyan una cronología en torno al año 1055. 
"PERO EL ORO Y LA PLATA, Y TODAS LAS COSAS DE BRONCE Y DE HIERRO, SERÁN DEDICADAS AL SEÑOR Y SE PONDRÁN EN SU TESORO" (JOS. 6, 19)

Para concluir el análisis de esta nueva escultura queremos desarrollar algunas hipótesis finales.

El templo dedicado a San Juan Bautista y que a partir del año 1063 honró a San Isidoro contó con un complejo desarrollo visual materializado en lenguaje románico. Los ejemplos que hemos conservado, especialmente desde las artes suntuarias así lo demuestran. Sobre los altares de aquel pobre edificio se desplegaron los recursos más novedosos conocidos hasta la fecha en el marco medieval hispano.

A ello habrá de sumarse, resulta evidente, la lógica articulación del espacio litúrgico, hecho demostrado por el fragmento de cancel procedente, según Williams, de aquel edificio y que ahora presentamos en una nueva visión reconstruida.

No tenemos dudas de que la escultura en piedra existió en aquel templo. De confirmarse que el último de los canecillos con modillones vueltos y rostro barbado perteneció a la cornisa de este edificio ${ }^{119}$, podríamos hablar de una estructura que presentaba un alero propio de la tradición románica. El uso del ajedrezado en escultura arquitectónica tendría sus tempranos ecos dentro de la arqueta de San Pelayo. Sin embargo, como digo, esta conjetura, aún en beneficio de mi trabajo, no puedo demostrarla ni validarla por ahora a la vista de las secuencias constructivas defendidas por otros autores ${ }^{120}$.

De lo que no dudo es de la relación entre la escultura pétrea del templo de Fernando I y las artes suntuarias comandadas

${ }^{119}$ H. BREDEKAMP y F. SEEHAUSEN, “Das Reliquiar als Staatsform. Das Reliquiar Isidors von Sevilla und der Beginn der Hofkunst in León", Reliquiare im Mittelalter, Berlin, 2005, pp. 137-164.

${ }^{120}$ G. BOTO VARELA, “In Legionenssy...”, p. 98. para celebrar la llegada del cuerpo del hispalense a León. Antes de la renovación del tesoro tras el Concilio de Coyanza, aquel espacio contó con una arqueta pétrea cuya ornamentación preludió los grandes programas del románico que hoy conocemos en el centro. La iconografía del relieve perdido, con los cuatro vivientes y el Agnus Dei, es cierto, muestra las herencias propias de la plástica coetánea -como la pila bautismal- y perpetúa su vinculación con la miniatura de los siglos X y XI, pero, por encima de todo, demuestra lo importantes que debieron ser las experiencias plásticas del pasado fernandino para el arte del tiempo de la infanta Urraca $^{121}$.

Con frecuencia los investigadores se preguntaron por la relevancia y persistencia iconográfica del Agnus Dei en San Isidoro, materializado en un corto espacio de tiempo tanto en la fachada del Cordero como en el tímpano pintado que permitía la comunicación del panteón con la igle$\operatorname{sia}^{122}$.

Ejemplos como el de este relieve deben permitir suponer que, antes de utilizar relaciones foráneas como hitos justificativos del arte románico isidoriano en torno al año 1100, habría que continuar profundizando en el conocimiento de aquel edificio construido y ornamentado bajo la comitencia de Fernando I, bien a pesar de las dificultades que conlleva su destrucción íntegra.

${ }^{121}$ F. PRADO-VILAR, "Lacrimae rerum: San Isidoro de León y la memoria del padre", Goya, 328, 2009, pp. 195-221. Los análisis de la estereotomía revelan una factura idéntica en las fábricas de Fernando I y la infanta Urraca y, en el mismo sentido, personalmente defendemos que padre e hija compartieron canteros, escultores y orfebres en unos proyectos artísticos íntimamente ligados. Sobre la lectura de muros, véase: G. BOTO VARELA, “In Legionenssy...”, p. 120.

122 J. A. MORÁIS MORÁN, "La efigie esculpida del Rey David en su contexto iconográfico. Una poética musical para la apotheosis celestial en la portada del Cordero de San Isidoro de León", Imágenes del poder en la Edad Media. Estudios in memoriam del Prof. Dr. Fernando Galván Freile, León, 2011, vol. II, pp. 355-374. 
Los modelos en piedra de aquella iglesia fundamentaron, parcialmente si se quiere, las soluciones desarrolladas en el arte posterior. De los temas vegetales del cancel pudieron tomar las referencias los orfebres que facturaron algunas cenefas de la arqueta del hispalense. De la iconografía del relieve que se ha estudiado tomaron las formas conceptuales, evidentemente mejorándolas y refinándolas, los artífices de la arqueta de San Pelayo, ejecutada tan sólo una década después en lenguajes renovados y materiales más ostentosos acordes con la legislación conciliar.
No encontramos otra contextualización para esta arqueta, cuya fecha post quem parece anclarse, posiblemente, en ese año 1055, época de renovación absoluta y de confirmada largueza por parte del entorno regio. Un año, no ha de pasarse por alto, en el que la reina Sancha encomienda el Diurnal ${ }^{123}$. En esta fecha tan temprana el románico era una realidad en San Isidoro, en la escultura pétrea, en la ilustración del libro y, cuatro años después -al menos en lo documentado-, en las artes suntuarias. Sólo faltaría, finalmente, aclarar la naturaleza románica de su arquitectura de la que, por ahora, lamentablemente nada podemos preguntarle al edificio.

${ }^{123}$ Biblioteca de la Universidad de Santiago de Compostela, Ms. 609, Res. 1. Cf.: F. GALVÁN FREILE, “La producción de manuscritos iluminados en la Edad Media y su vinculación a las monarquías hispanas", Anuario del Departamento de Historia y Teoría del Arte, 13, 2001, pp. 37-52, particularmente, pp. 39-48. 